
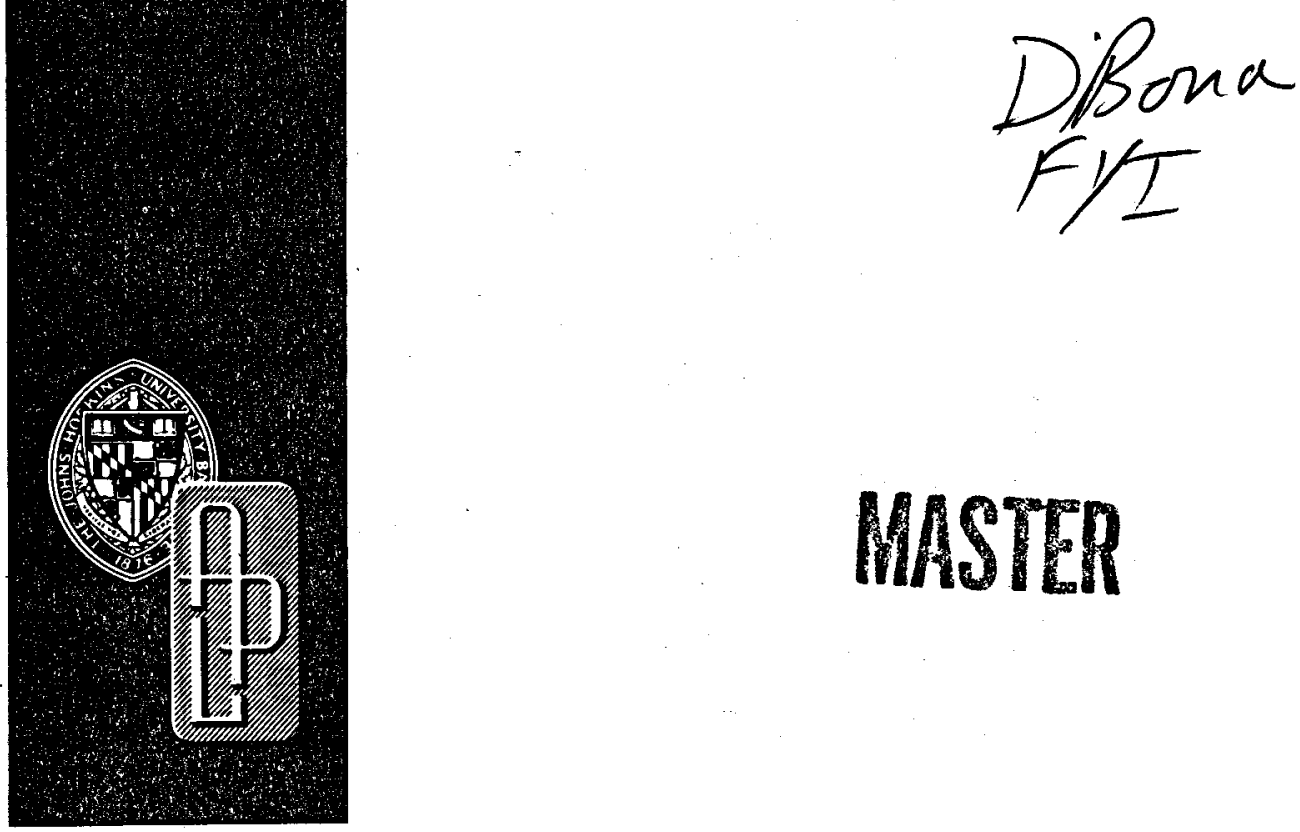

$\mathrm{APL} / \mathrm{JHU}$

QM-79-163/GT

JULY 1979

Copy No.

Geothermal Energy Development in the Eastern United States

\title{
EVALUATION OF POTENTIAL GEOTHERMAL RESOURCE AREAS
}

FRANKLIN O. MITCHELL

This work was supported by the Department

of Energy under Interagency Agreements

EX-76-A-36-1008 and DE-Alo1-79ET27025

THE JOHNS HOPKINS UNIVERSITY - APPLIED PHYSICS LABORATORY 


\section{DISCLAIMER}

This report was prepared as an account of work sponsored by an agency of the United States Government. Neither the United States Government nor any agency Thereof, nor any of their employees, makes any warranty, express or implied, or assumes any legal liability or responsibility for the accuracy, completeness, or usefulness of any information, apparatus, product, or process disclosed, or represents that its use would not infringe privately owned rights. Reference herein to any specific commercial product, process, or service by trade name, trademark, manufacturer, or otherwise does not necessarily constitute or imply its endorsement, recommendation, or favoring by the United States Government or any agency thereof. The views and opinions of authors expressed herein do not necessarily state or reflect those of the United States Government or any agency thereof. 


\section{DISCLAIMER}

Portions of this document may be illegible in electronic image products. Images are produced from the best available original document. 
APL/JHU

QM-79-163/GT

JULY 1979

\section{EVALUATION OF POTENTIAL GEOTHERMAL RESOURCE AREAS.}

FRANKLIN O. MITCHELL

This work was supported by the Department of Energy under Interagency Agreements EX-76-A-36-1008 and DE-Alo1-79ET27025

THE JOHNS HOPKINS UNIVERSITY APPLIED PHYSICS LABORATORY Johns Hopkins Road, Laurel, Maryland 20810

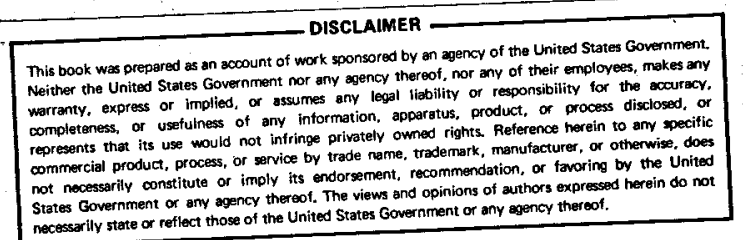



A method for the comparative evaluation of geothermal prospects in the Eastern United States is proposed and 11lustrated. Comparisons are based on quantified data from geologic, engineerIng, and soctomeconomlc sources including temperature gradient, depth to basement, drilling costs, population, and distribution by town size, as well as energy use in residential, commercial, and Industrial applications. 

THE JOHNS HOPKINS UNIVERSTY APPLIED PHYSICS LABORATOAY

LAUREL. MARYLAND

\section{PREFACE}

This report is one of a series by The Johns Hopkins University Applied Physics Laboratory in its role of supporting the development of geothermal energy in the Eastern United States. Prior reports are listed below.

Planning Scenarios - to assist states and DOE in planning for geothermal development:

"Geothermal Energy and the Eastern U.S., a Scenario for Geothermal Energy Development, the Atlantic Coastal Plain," APL/JHU QM-77-129, Oct 1977.

"Geothermal Energy and the Eastern U.S., a Scenario for Geothermal Energy Development, the Coastal

Plain in Southern Arkansas," APL/JHU QM-77-129-1, Oct 1977.

"Geothermal Energy and the Eastern U.S., a Scenario for Geothermal Energy Development, the Madison Limestone Aquifer in Western South Dakota," APL/JHU QM-77-129-2, Nov 1977.

"Geothermal Energy and the Eastern U.S., a Scenario for Geothermal Energy Development, the Eastern Gulf Coastal Plain," APL/JHU QM-77-129-3, Feb 1978.

"Geothermal Energy and the Eastern U.S., a Draft Scenario for Geothermal Energy Development, Hot Dry Rock," APL/JHU QM-77-129-4, Mar 1978.

*"Potential Application of Madison Formation Waters for Community Heating - South Dakota," APL/JHU QM-78-042R, Sep 1978 .

"Geothermal Energy Development by Oglala Sioux at Kyle, South Dakota," APL/JHU QM-78-226, Apr 1978.

*"A Review of Recent Energy Price Projections for Traditional Space Heating Fuel 1985-2000," APL/JHU GEMS-005 (QM-79-016), Mar 1979.

*Avallable for distribution. 
*"Economic Evaluation Model for Direct Use of Moderate Temperature (up to $250^{\circ} \mathrm{F}$ ) Geothermal Resources in the Northern Atlantic Coastal Plain," APL/JHU GEMS-003 (QM-79-124), Jun 1979.

"Fact Sheets Relating to the Use of Geothermal Energy (Eastern United States)," APL/JHU QM-79-037, Jan 1979.

*"A Framework for a Site Prospectus for Geothermal Energy Development - Delmarva Peninsula," APL/JHU QM-79-145, Jun 1979.

The work feported here was initlated under the direction of Mr. Robert 0liver in the Planning office of the Division of Geothermal Energy. It was completed under the direction of Mr. W. L. R. Rice, Offlce of the Resource Manager for Geothermal Energy Resource Applications.

*Avallable for distribution. 


\section{CONTENTS}

List of Illustrations • • • • . . . 9

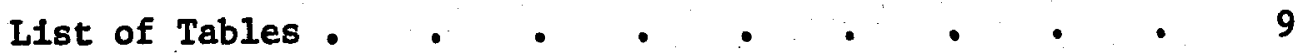

1. Introduction and Background . . . . . 11

2. Overview -.$\quad$ - . . . . . 12

3. The Data • • . • . . . . . 14

Depth and Gradient . . . . . . . . 14

Population and Distribution of Towns by Size . . 14

Heating Degree Days • • . . . . . . . 21

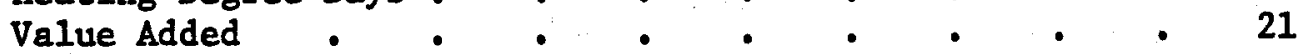

4. Derived Elements of the Bases of Comparison - - 22

Temperature and Extractable Heat - . . . . 22

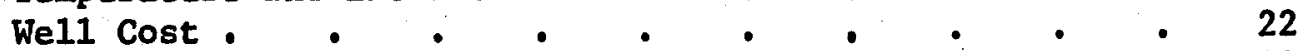

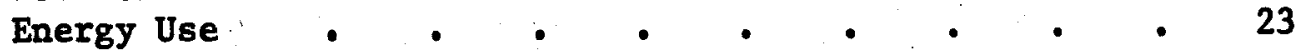

5. The Method . . . . . . . . . 24

6. Examples and Results . . . . . . . . 26

7. Review . . • . . . . . . . . 28

8. Future Work • • • . • • • . . 29

References • • . . . . . . . 31

Appendix A: Maps of States Showing the Countries Selected as Geothermal Prospects . . . . 33

Appendix B: Ranked Prospects under Different Criterla . 51 



\section{ILLUSTRATIONS}

1 Geographical areas covered in comparative evaluation - 15

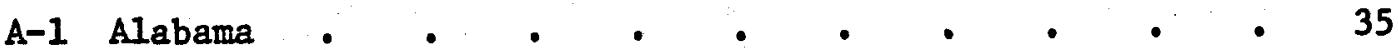

A-2 Arkansas • . . . . . . . . . . . . 36

A-3 Georgia • • • • • • • • • • • 37

A-4 Illinols • . • . . . . . . . 38

A-5 Indiana . . . . . . . . . . . 39

A-6 Kansas . $\quad . \quad$. . . . . . . . 40

A-7 Michigan . . . . . . . . . . . 41

A-8 M1ssissipp1 . . . . . . . . . 42

A-9 M1ssour1 . . . . . . . . . . 43

A-10 New Jersey $\quad$ • . . . . . . . . 44

A-11 New York • . . . . . . . . . 45

A-12 North Carolina . . . . . . . . . 46

A-13 Ohio . . . . . . . . . . . . 47

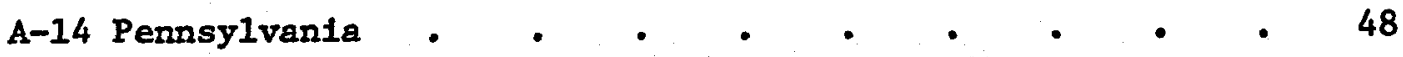

A-15 South Carolina . . . . . . . . . . . 49

Tables

1 Geologic, geothermal, demographic, and Industrial

data . . . . . . . . . 16

2 Select prospects under different criterla . . - 27 


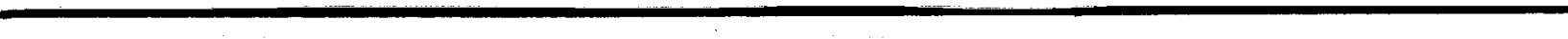


THE JOHNS HOPKINS UNIVERSITY

LAUREL. MARYLAND

1. INTRODUCTION AND BACKGROUND

The Applied Physics Laboratory (APL), in its role of supportIng the development of geothermal energy in the Eastern United States, has developed a method for comparing potentlal geothermal resource areas in the region. A description of the method and a summary of initial results are presented herein.

The Department of Energy (DOE) maintains an active program to target, confirm, and assess geothermal resources on the Atlantic Coastal Plain. In addition, DOE and selected states are participatIng in foint programs to define geothermal characteristics within those states. To coordinate the results of the work and to give direction to future efforts require a systematic and synoptic technique for examining the geothermal potential of the area. Also needed is a quantitative technique for evaluating alternative future federal resource allocation strategies in support of DOE/DGE (Division of Geothermal Energy) and DOE/RA (Resource Application) programs intended to stimulate the commerclalization of low to moderate temperature geothermal resources.

This report presents a relatively stralghtforward method to satisfy both needs. The method combines geologic, engineering, and economic factors at the county level where the data are avallable. As data become available for a state not previously included or better data become avallable for an included area, the entire set of prospects can be reassessed readily. 


\section{OVERVIEW}

Comparative evaluations of geothermal prospects must consider geologic, engineering, and socio-economic information. Because the data are most readily avallable at the county level, the prospects are evaluated at that level in this report.

The proposed method for comparing prospects is an outgrowth of work during the $1940^{\prime} \mathrm{s}$ arising from the von Neumann-Morgenstern axiomatization of utility (Ref. 1) and is related to the work of Arrow and Goodman at the Cowles Commission in the $1950^{\prime} \mathrm{s}$. Goodman's review (Ref. 2) of the work is the basic reference for this application.

Consider a matrix in which the prospects are presented as rows and the columns represent the several bases of comparison. An algorithm assigns a score that measures the preference for that prospect to each row of the matrix. Because comparisons must be made relative to some purpose, the method makes a clear distincton between the basis of comparison and the weight that must be associated with it for the stated purpose. (We anticipate that the purpose for which a comparative evaluation is conducted will vary with the point of view and with the echelon of the office needing the evaluation.) The algorithm scores prospects by rankIng the columns individually and then takes a weighted average of the rankings in the columns for each prospect.

The bases of comparison fall into three broad categories: characteristics of the prospective resources, cost factors, and market factors.

The first, resource characteristics, is limited by the avallability of uniform data to estimate the resource temperature and the extractable heat (in Btu/ga1). It is assumed that extractable water exists at some depth in each prospective area. When rellable data on water avallability and flow rate are obtainable, they can be taken into consideration.

Cost factors are limited to the cost of drilling and casing wells because of the availability of American Petroleum Institute (API) data. Other engineering costs are too site-specific to be included. Engineering cost studies being pursued in the energy community may well develop useful measures that can be included in the future. 
THE JOHNS HOPKINS UNIVERSITY APPLIED PHYSICS LABORATORY

LAUAEL, MARYLAND

Market factors contain measures that relate to the current use of energy for residential, commercial, and industrial purposes and for space heating demands.

The data we have assembled for deriving the bases of comparisons are considered only as convenient starting points to make comparisons. As field work progresses and as new statistics are evolved from energy programs, comparisons between geothermal prospects can be expected to change, both quantitatively and qualitatively. 


\section{THE DATA}

Data have been gathered for 226 counties in 16 states to 11lustrate the method for assessing geothermal potentlal (Table 1). The first seven columns are taken from published sources; the last six collumis are derived from them. U.S. Department of Comnerce maps are included in Appendix A. The counties selected as prospects have beèn shaded for emphásis.

\section{DEPTH AND GRADIENT}

Comparisons were restrlicted to sedimentary basins where subsurface temperatures and driling costs are known from previous explorations for hydrocarbons. Moreover, the potential for locating and extracting water as a heat exchange medium is greater in sedimentary sequences than in crystalline terraces (Ref. 3).

Information on depths to basement and geothermal gradients is pubilished by the U.S. Geological survey (Refs. 4 and 5). The data for geothermal gradients are incomplete for parts of the Eastern Onlted States, notably New England, eastern New York, along the Appalachlans; and central Missouri (see Fig. 1). The data from the two Yeference maps (Refs. 4 and 5) were plotted to a comon scale. Counties were selected where the depth to basement was greater than $1000 \mathrm{ft}$ (the assumed minimum value needed for insulation) and the geothermal gradient exceeded $1.6^{\circ} \mathrm{F} / 100 \mathrm{ft}$.

Areas where data were incomplete were omitted, but no Impi1cation is intended that they might not be valid geothermal prospects according to some other criterion or source of data. Both the gradlent and the depth to basement vary over areas as large as $a$ county columins 1 and 2 of Table 1 give estimates of averages of the dépths and gradients of the whole county using the cited references. Maps giving greater detail are available for site selection within the county.

\section{POPULATION AND DISTRIBUTION OF TOWNS BY SIZE}

Estimates of the population of the states, counties, and towns for 1976, published by the Bureau of the Census (Ref. 6), are reproduced in column 3 of Table 1 . The distribution of towns by size was determined by classifying the town populations as follows: 

THE JOHNS HOPKINS UNIVERSTY

APPLIED PIYSICS LABORATORY

LAUREL. MaRYLAND

Table 1

Geologic, geothermal, demographic, and industrial data.

(States and counties where thermal gradient exceeds

$\left.1.6^{\circ} \mathrm{F} / 100 \mathrm{ft}.\right)$

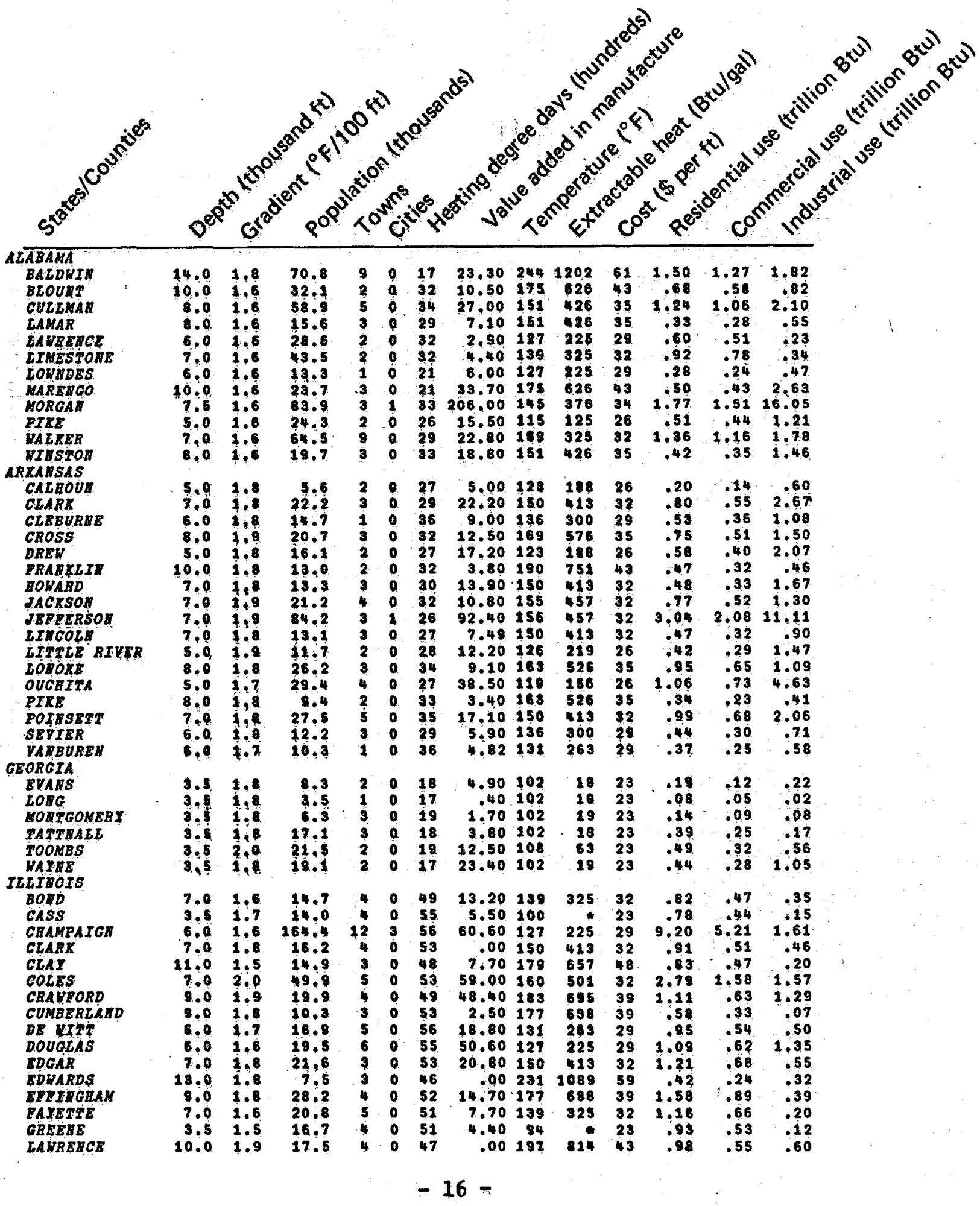


THE JOHNS HOPKINS UNIVERSITY

APPLIED PHYSICS LABORATORY

LAUREL, MaAYLAND

Table 1 (cont'd)

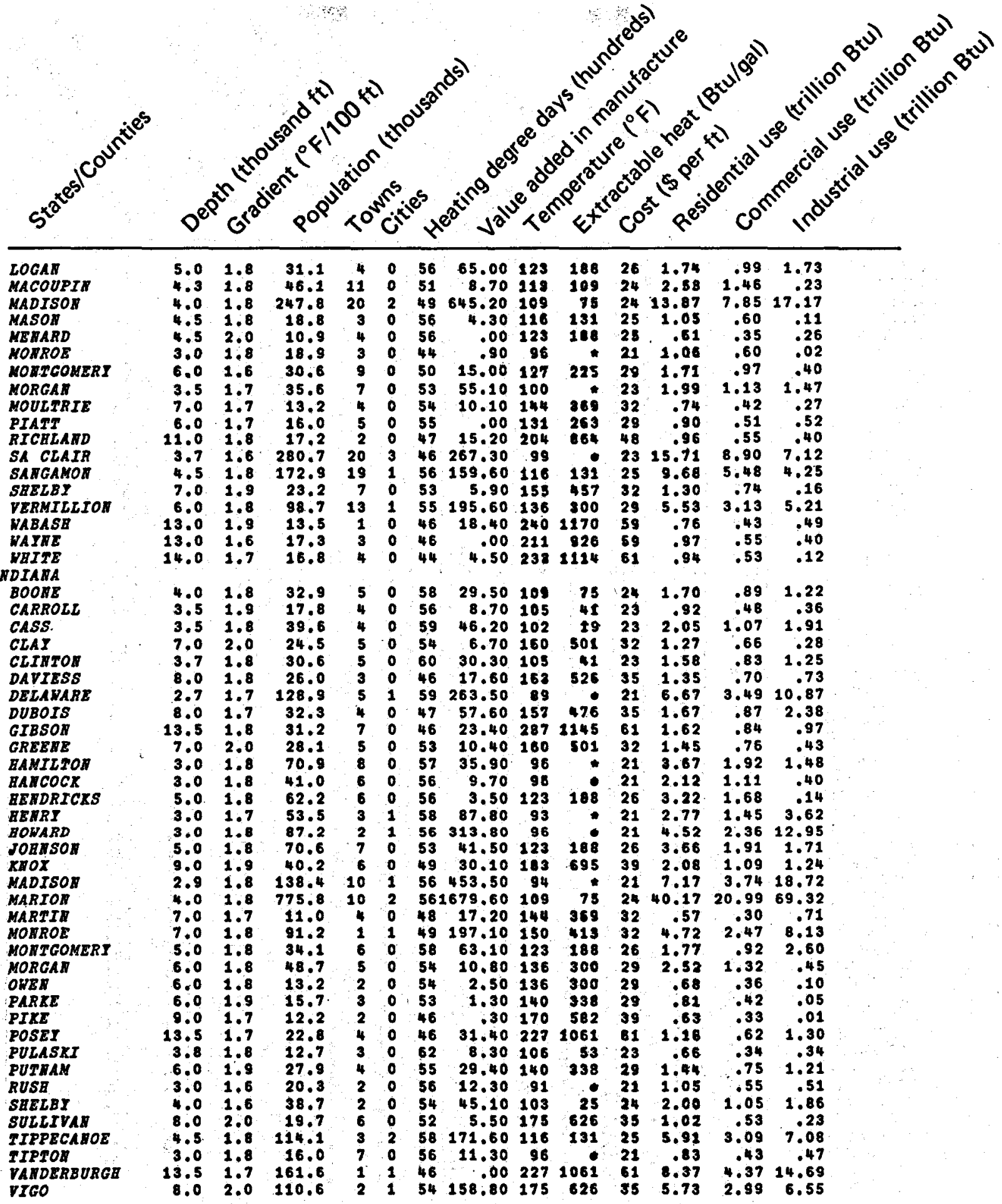


Table 1 (cont'd)

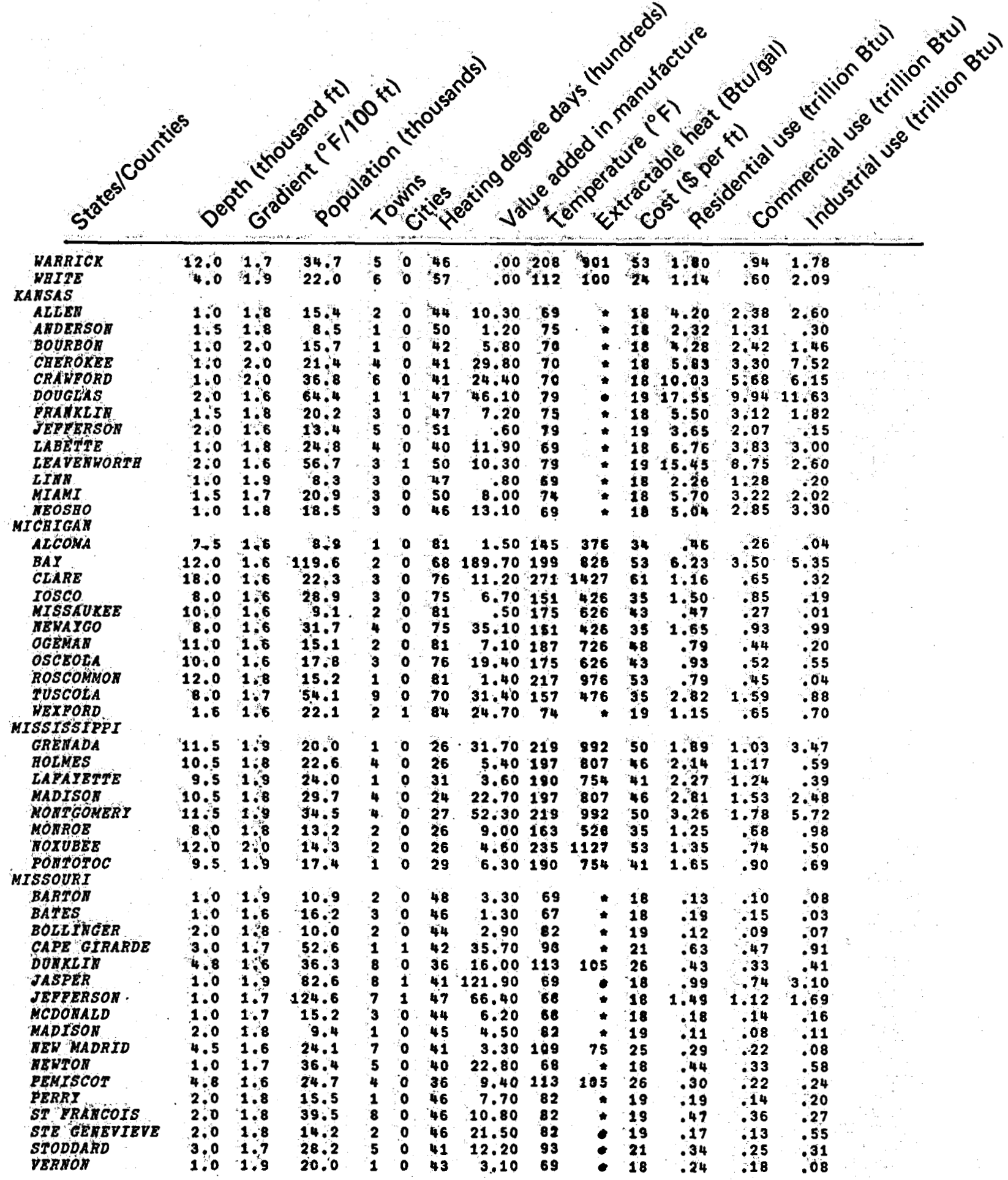


THE JOHNS HOPKINS UNIVERSITY

APPLIED PHYSICS LABORATORY

LAUAEL, MARYLAND

Table 1 (cont'd)

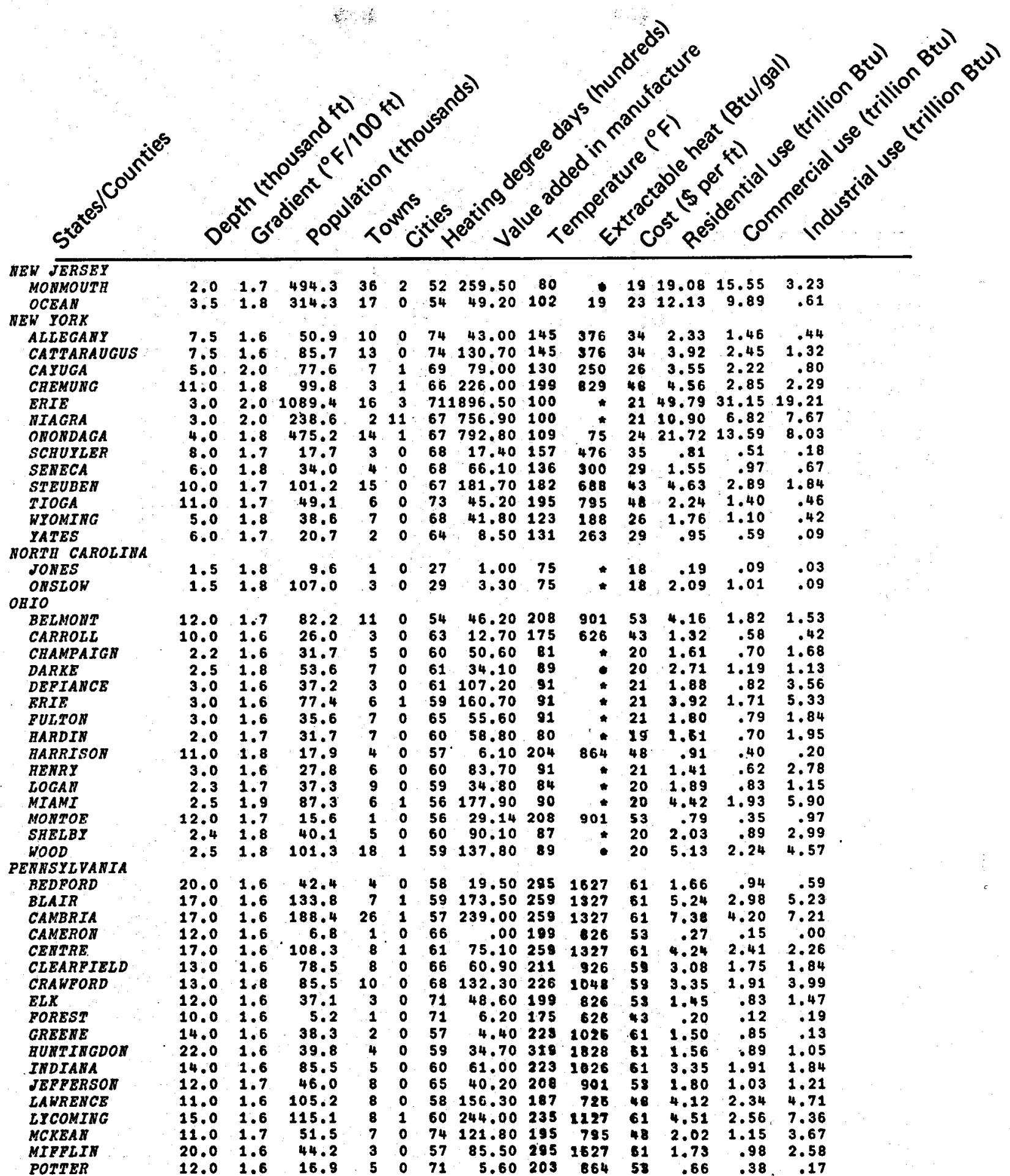


THE JOHNS HOPKJNS UNIVEASTY

APPLIED PHYSICS LABORATORY

LAUREL. MARYLAND

Table 1 (cont'd)

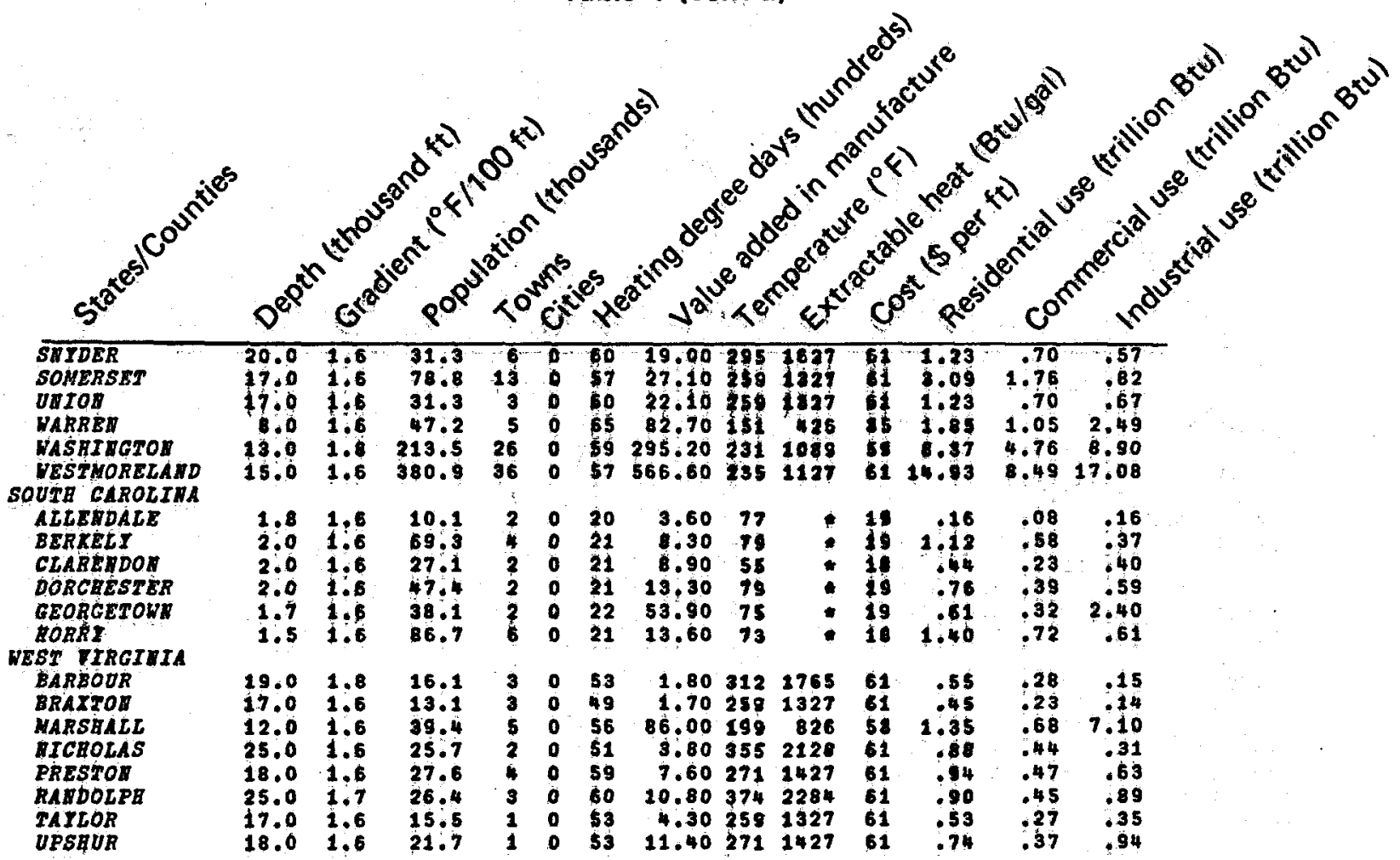


THE JOHNS HOPKINS UNIVERSITY APPLIED PHYSICS LABORATORY LAUREL, MARYLANO

$$
\begin{gathered}
0-250 \\
251-500 \\
501-1000 \\
1001-2500 \\
2501-5000 \\
5001-10000 \\
10001-20000 \\
\text { over } 20000 .
\end{gathered}
$$

Column 4 gives the total count of incorporated places with populations between 500 and 20000 ; column 5 gives the number of Incorporated places with populations greater than 20000.

\section{HEATING DEGREE DAYS}

The normal annual numbers of heating degree days are published by the National Climatic Center (Ref. 7) for the several National Weather Service offices and principal climatological stations within each state. The normals vary considerably from station to station. The normals for the counties (column 6) have been obtained by using the value for a station within the county or the average of the values if there is more than one station. When no station is listed within a county, the value has been determined by interpolation from nearby stations, using two or three palrs of stations where possible. All tabulated values have been rounded to the nearest hundred degree days. From a study of the data, this precision seems to be adequate for this report.

VALUE ADDED

Data on value added in manufacturing (1967), published by the Bureau of the Census (Ref. 8) for the states and countles, are reproduced as column 7 of Table 1 . Value added in manufacture is the difference between the total cost of materials and energy and the value of shipments of the finished product adjusted for the change in inventories at the beginning and end of the year. 


\section{DERIVED ELEMENTS OF THE BASES OF COMPARISON}

TEMPERATURE AND EXTRACTABLE HEAT

The temperature of the resource is estimated arbitrarily at $75 \%$ of the depth to basement, assuming $55^{\circ} \mathrm{F}$ as the normal ground temperature. Extractable heat (in Btu/gal) is ealculated using a spent-water temperature of $100^{\circ} \mathrm{F}$. This quantity is not now used in the bases of comparison since it is a linear function of estimated temperature; however, it is retained in Table 1 for use when flow rates are available.

The following equations are used in the calculation:

$$
\begin{aligned}
& T=55+G \times(0.75 \times D), \\
& Q=8.34 \times(T-S),
\end{aligned}
$$

where

I Is temperature of the resource,

$G$ is gradient,

D is depth,

$Q$ is extractable heat, and

S is spent-water temperature.

In Table 1, temperature and extractable heat, rounded to the nearest unit, are listed in columns 8 and 9 . This precision Is unwarranted by the data but is required in order to retain a consistent correlation between the two columns. Counties marked with an asterisk do not have sufficient extractable heat to warrant further consideration as geothermal prospects.

WELL COST

The cost of drilling and casing an $8 \mathrm{in}$. well was discussed by Milora and Tester (Ref. 9). The cost curves can be fitted by the following equation:

$$
C_{w}=10^{K+D / 17140},
$$


where

$C_{w}$ is well cost per foot in 1976 dollars,

$D$ is depth in feet, and

$K$ is 1.6 in hard rock or

1.2 in soft rock.

These costs have been compared with those published by API (Refs. 10 and 11). The very high costs that occasionally are published seem to result from off-shore drilling and drilling to very great depths rather than from inflation. The estimates derived using the above equation seem to be adequate for wells in the locations of interest in this report and for depths less than $10000 \mathrm{ft}$.

\section{ENERGY USE}

Information on energy use in residential, commercial, and industrial sectors according to type of fuel was collected and published in the Geothermal Fact Sheets (Ref. 12). For this report, the energy use in each sector was determined by summing the use of each fuel type except "electricity purchased," under the assumption that electrical energy usually would not be replaced by geothermal energy in the regions under consideration. The residential and commercial use of energy for each state was then apportioned to the counties on the basis of population.

The industrial use of energy in the state was apportioned to the counties on the basis of value added in manufacturing. If value added is not disclosed in Ref. 8, Industrial energy is apportioned to the counties on the basis of the number of manufacturing establishments. 
The method discussed below 1 s based on the definite opinion that there will never be adequate data or a clear pollcy that will determine, once and for all, the strategy to be followed in the commercialization of geothermal energy. From this point of view, it Is clear that the available data must be assessed according to criteria and policles that are given as much visibility as possible so that new data or a change in the purpose for which the evaluation of a strategy is undertaken can be accomodated.

This method evaluates alternative strategies by ranking the geothermal prospects. The ranking is carried out by amalgamating the assessments of the prospects according to several bases of comparison. The process of amalgamation requires that the different bases of comparison be assigned weights to indicate the importance of each basis to the overall purpose of the evaluation.

To state the problem more formally, consider a matrix in which the prospects to be ranked are presented as rows and the columns represent the bases of comparison. The problem is to devise rules for selecting the "best" row. If the elements of the matrix can be interpreted as "utilities" in the von Neumann-Morgenstern sense, there are a number of methods of amalgamation that might be considered (Refs. 1 and 2). However, the natural bases of comparison for ranking geothermal prospects are as disparate as temperature and population.

To improve the comparability, each basis can be scaled to the unit interval, or ranks can be assigned to each basis separately. Where a natural scaling exists (e.g., the boiling point of water), the scallng method has some advantages, but for the present problem natural scalings are not immediately apparent. The method of rankIng each basis separately has therefore been adopted, with 1 the highest rank, 2 the next highest, and so on. Tled ranks are replaced with their averages. Observe that functions of the data in a column that preserve order (in particular, linear functions) do not change the assigned ranks.

The bases of comparison are selected from the available data in order to satisfy in part the purpose of the evaluation. Another way to reflect the policy or purpose is to recognize that the elements of the bases do not enter equally into consideration. Each column must be weighted in accordance with its importance. 
where

$S$ is the weighted score for each row,

$C$ is the matrix of ranks of the bases of comparison, and

$W$ is a column matrix of the weights to be assigned each element of the basis (each column).

The operation in this formula is ordinary matrix multiplication. The scores obtalned represent a weighted average of the ranks assigned to each prospect; the row with the lowest score is the "best" prospect. The scores themselves are ranked in the tables accompanying the example for easier reading.

The proposed ranking scheme can be carried out by hand or on a pocket calculator for small data bases. As the data bases become larger, the work becomes tedious, and a small set of computer routines has been coded to handle them. 
The examples given below may make the proposed method seem less abstract and may provide insight into the way ranks change under different criteria. It should be understood that what is proposed is a method of ranking a given set of prospects; it is not a selection of prospects. The partlcular set of counties used In the example was chosen because the data were readily avallable. Other prospects might be selected as being especially pertinent for exploration, for example, or other data may be used as the bases of compartson. In elther case, the additional prospects or the different criteria can be accommodated easily.

Examples of ranking are given for four categorles of development. The first overall ranking gives equal weight to temperature, cost, energy use in the three categories, the number of towns and citles, the number of heating degree days, and value added in manufacturing. The second ranking emphasizes residential use and selects as the bases of comparison temperature, well cost, current residential use of energy, the number of towns and cities, and the number of heating degree days. The third emphasizes comerctal applications and uses the same bases of comparison as the second except that the current commercial use of energy is substituted for residential use. The fourth emphasizes industrial development and selects temperature, well cost, current industrial use, the number of towns and cities, and value added in manufacturing.

In these examples, the weightings are always taken as equal although it is obvious that a particular criterion (e.g., the number of towns and citles) should have a greater importance under the residential criterion than under the industrial one. Appendix $B$ gives the ranks for all the prospects. Table 2 1ists 34 counties in 10 states that rank among the first 25 under at least one criterion. 
THE JOHNS HOPKINS UNIVERSTYY APPLIED PHYSICS LABORATORY LaUAEL, MaRylano

Table 2

Select prospects

under different criteria.

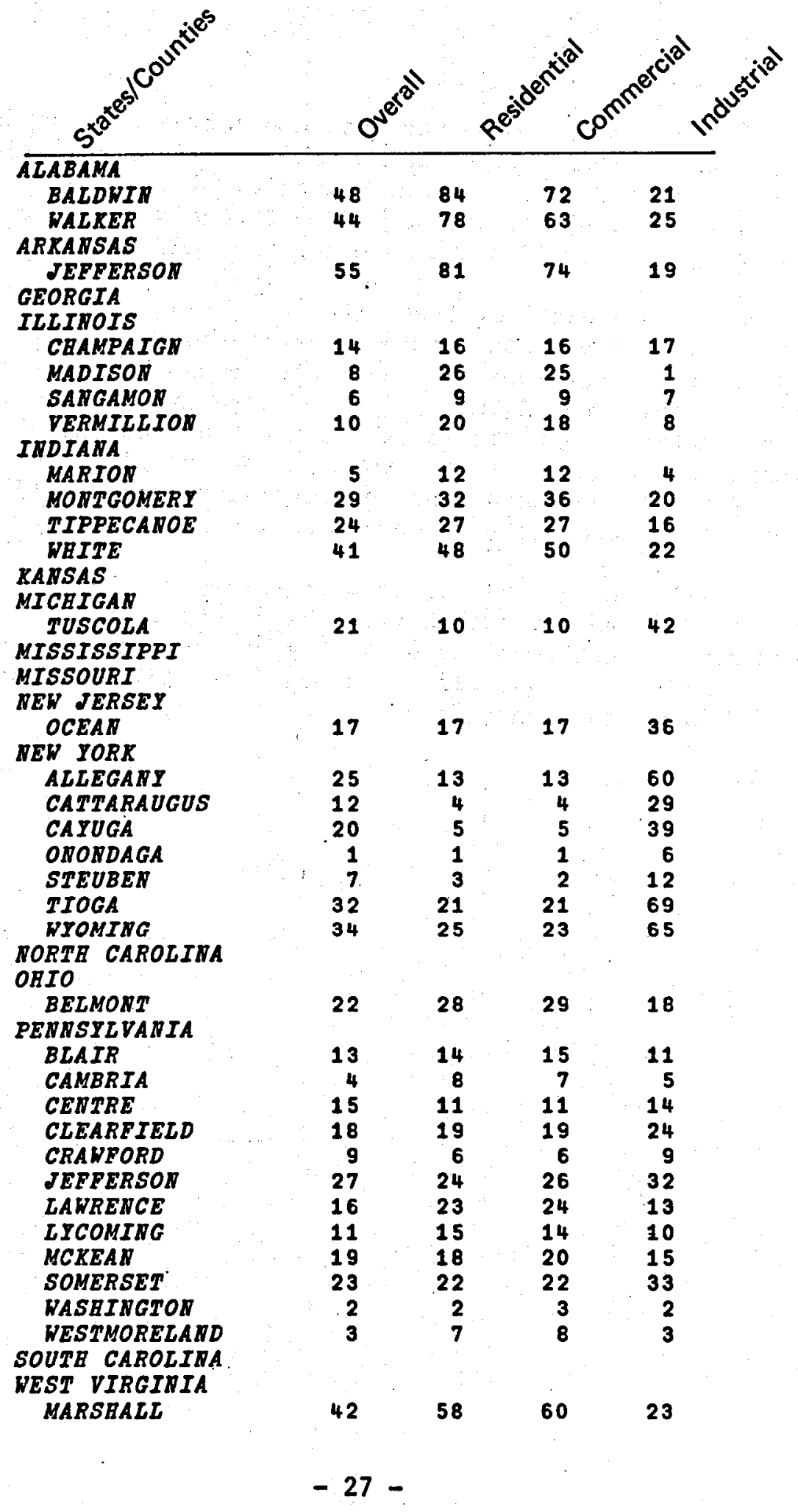


The proposed method presents a practical scheme for evaluatIng geothermal prospects by amalgamating evaluations arising from separate considerations of many criteria. The examples point up the fact that rankings vary according to one's point of view and to the purpose for which they are constructed.

Certain aspects of the method are being refined. The data on Industrial energy uses are being reconsidered. The present data may place too great an emphasis on high-temperature uses, espectally In Alabama and Pennsylvania. Sorting data by standard Industry code and by county would glve better estimates of the use of energy for process heat. Data are also avallable on the distribution of the use of process heat according to temperature and should permit a better match between the resource and its possible market.

Further consideration is being given to changing data categories to improve comparability. The transformation to ranks deemphasizes the nonlinearity of a category such as well cost. Transformation to a quantile function (Ref. 13) may provide a more faithful representation. 
The initial analysis did not include Texas, Loulsiana, and parts of the Atlantic Coastal Plain states. Data on these areas will be added in a supplemental report. The evaluation resulting from this method is proposed as one of the bases for the eastern portion of the hydrothermal resource confirmation plan being developed by DOE. 

1. J. von Neumann and 0. Morgenstern, Theory of Games and Economic Behavior, Princeton University Press, 1947.

2. L. A. Goodman, "On Methods of Amalgamation," Decision Processes, Thrall et al., Wiley and Sons, New York, 1954.

3. J. E. Tillman, "Geothermal Resources in the Eastern UnIted States," Geo-Heat 0. Bul1., Vo1. 4, No. 1, Nov 1978, pp. 4-6.

4. R. W. Balley and W. R. Muehlberger, "Basement Rock Map of the United States," U.S. Geological Survey, U.S. Department of Interfor, G67280, 1968.

5. American Association of Petroleum Geologists and U.S. Geological Survey, "Geothermal Gradient Map of North America," U.S. Geological Survey, U.S. Department of Interior, G74014, 1976.

6. "Current Population Reports, Population Estimates and Projectlons," Series P-25, Bureau of the Census, U.S. Department of Commerce, Jan 1979. (Separate numbers in the series are issued for population and estimates for counties and incorporated places in each state.)

7. National Climatic Center, "Monthly Normals of Temperature, Precipitation, and Heating and Cooling Degreee Days, 19411970," Climatography of the United States No. 81 (by state), National Oceanic and Atmospheric Administration, U.S. Department of Commerce, Aug 1973.

8. W. Lerner, "City and County Data Book, 1972," Bureau of the Census, U.S. Department of Commerce, 1973.

9. S. L. Milora and J. W. Tester, Geothermal Energy as a Source of Electric Power: Thermodynamic and Economic Design Criteria, Massachusetts Institute of Technology Press, 1976.

10. "1977 Joint Association Survey on Driliing Costs," American Petroleum Institute, Washington, Feb 1979.

11. "1976 Joint Association Survey on Drilling Costs," American Petroleum Institute, Washington, Dec 1977. 
12. "Fact Sheets Relating to the Use of Geothermal Energy (Bastern United States)," APL/JHU QM-79-037, Jan 1979 .

13. E, Parzeń, "Non-paranetilc Statistical Data Modeling," J. Am. Stat. Assoc., Vol. 74, No. 365, Mat 1979, pp. 105-121. 
THE JOHNS HOPKINS UNIVERSITY APPLIED PHYSICS LABORATORY LAUREL, MARYLAND

\section{APPENDIX A}

Maps of States Showing the Counties

Selected as Geothermal Prospects

(modified from Ref. 8) 
5

$\bar{E}$

$\omega$

$\ddot{1}$

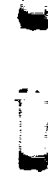

5

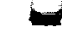

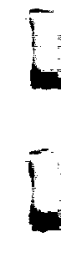

5

i

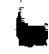

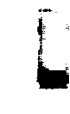

$\Gamma$

5

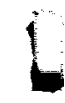

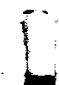

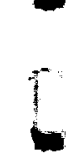

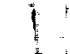

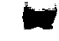

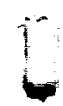

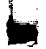


THE JOHNS HOPKINS UNIVERSITY APPLIED PHYSICS LABORATORY

LAUREL, MAAYLAND

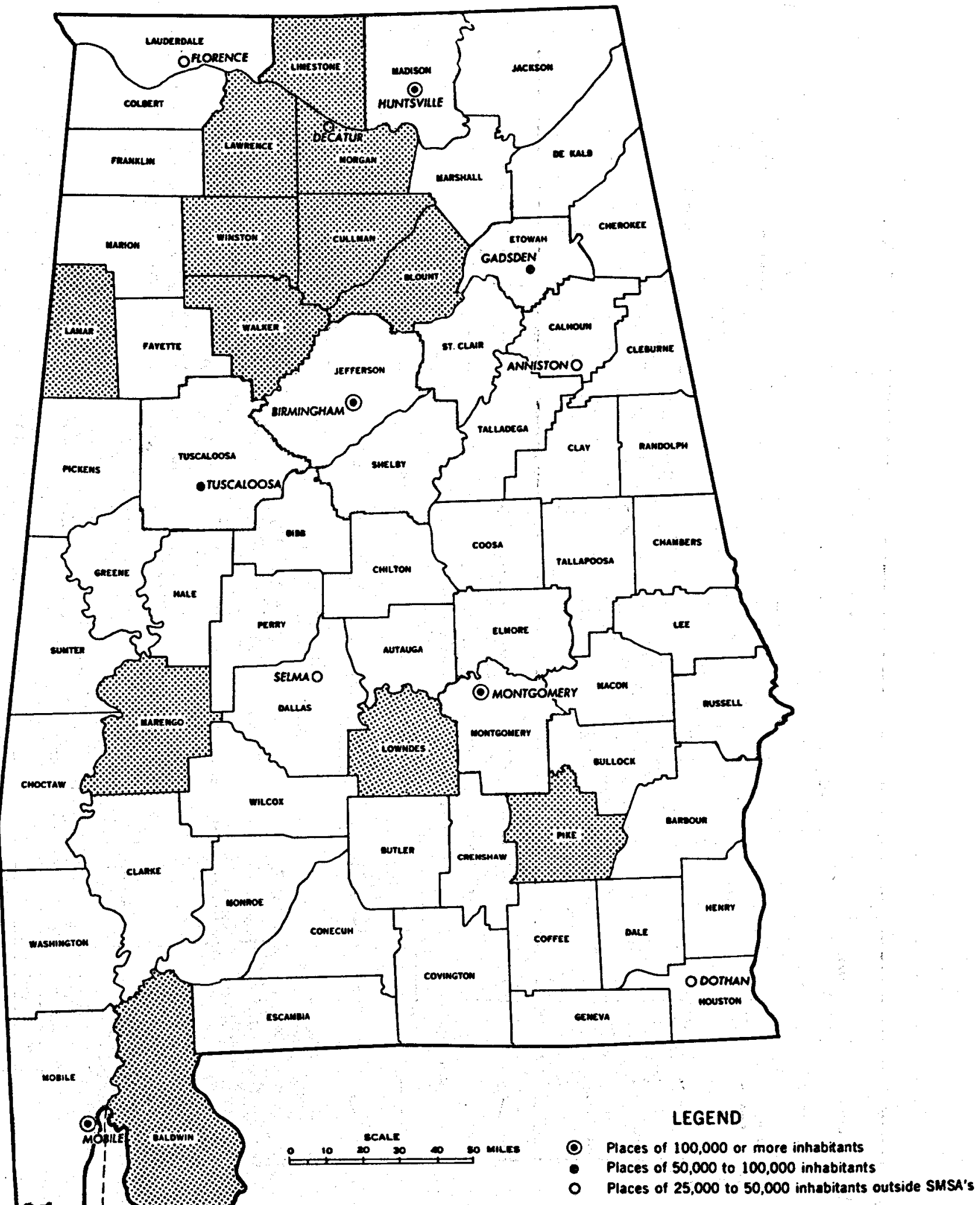

Fig. A-1 Alabama. 


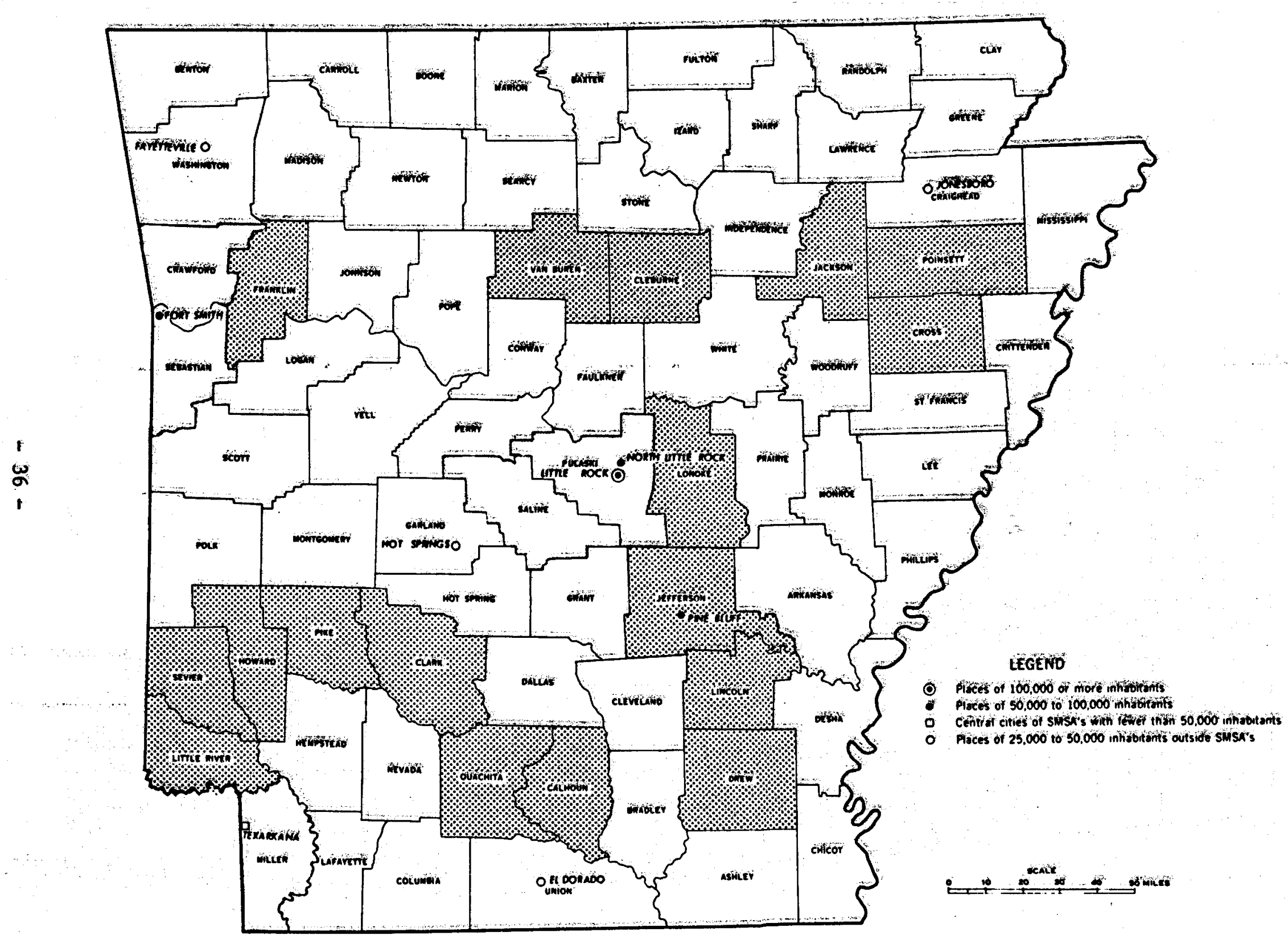

Fig. A-2 Arkänsas. 
THE JOHNS HOPKINS UNIVERSTY APPUED PHYSICS LABORATORY

LAUREL MARYLAND

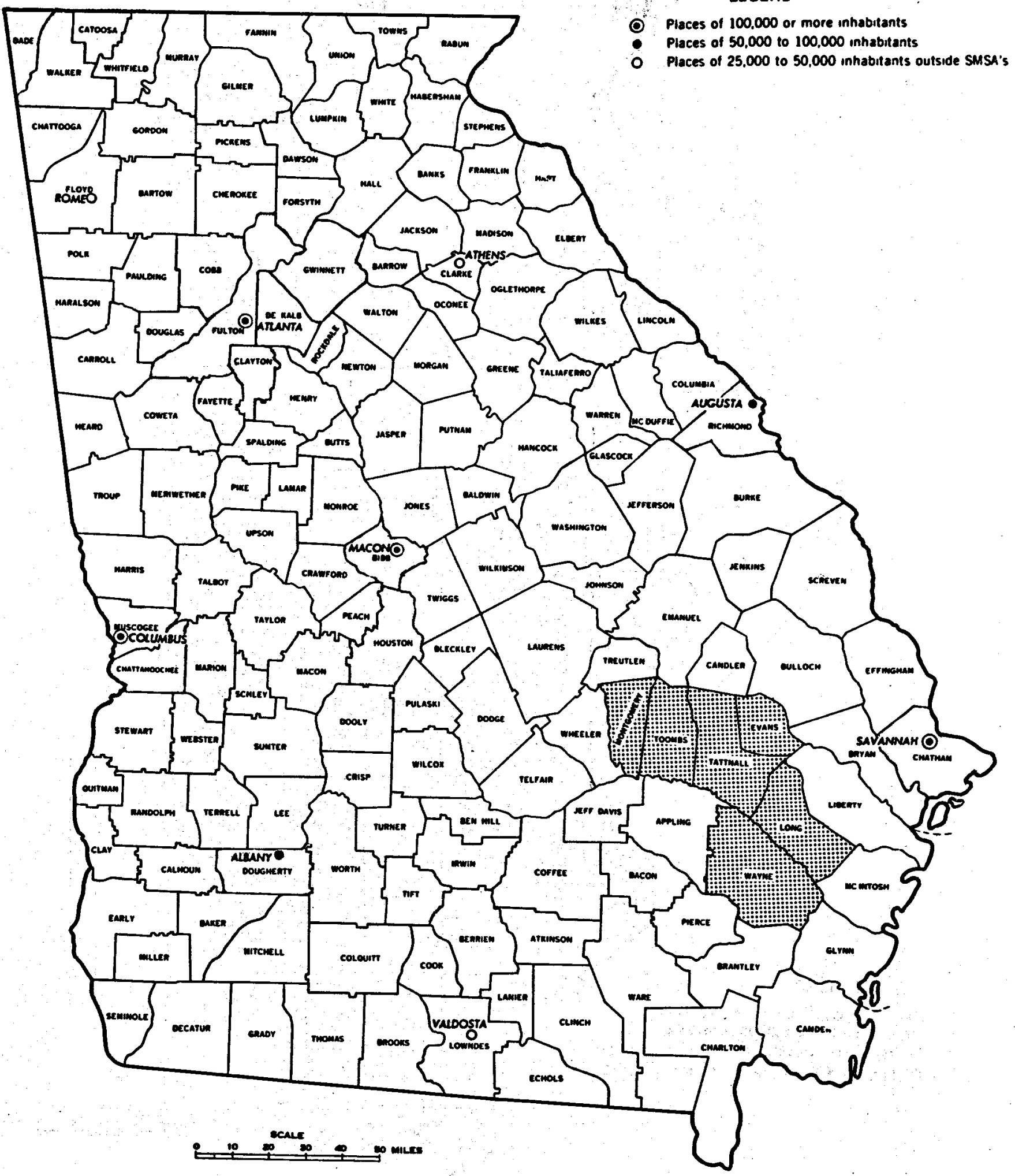

Fig. A-3 Georgia. 


\section{LEGEND}

Places of 100,000 or more inhabitants

- Places of 50,000 to 100,000 inhabitants

- Centrat cities of SMSA's with fewer than 50,000 inhabitants - Places of 25,000 to 50,000 inhabitants outside SMSA's
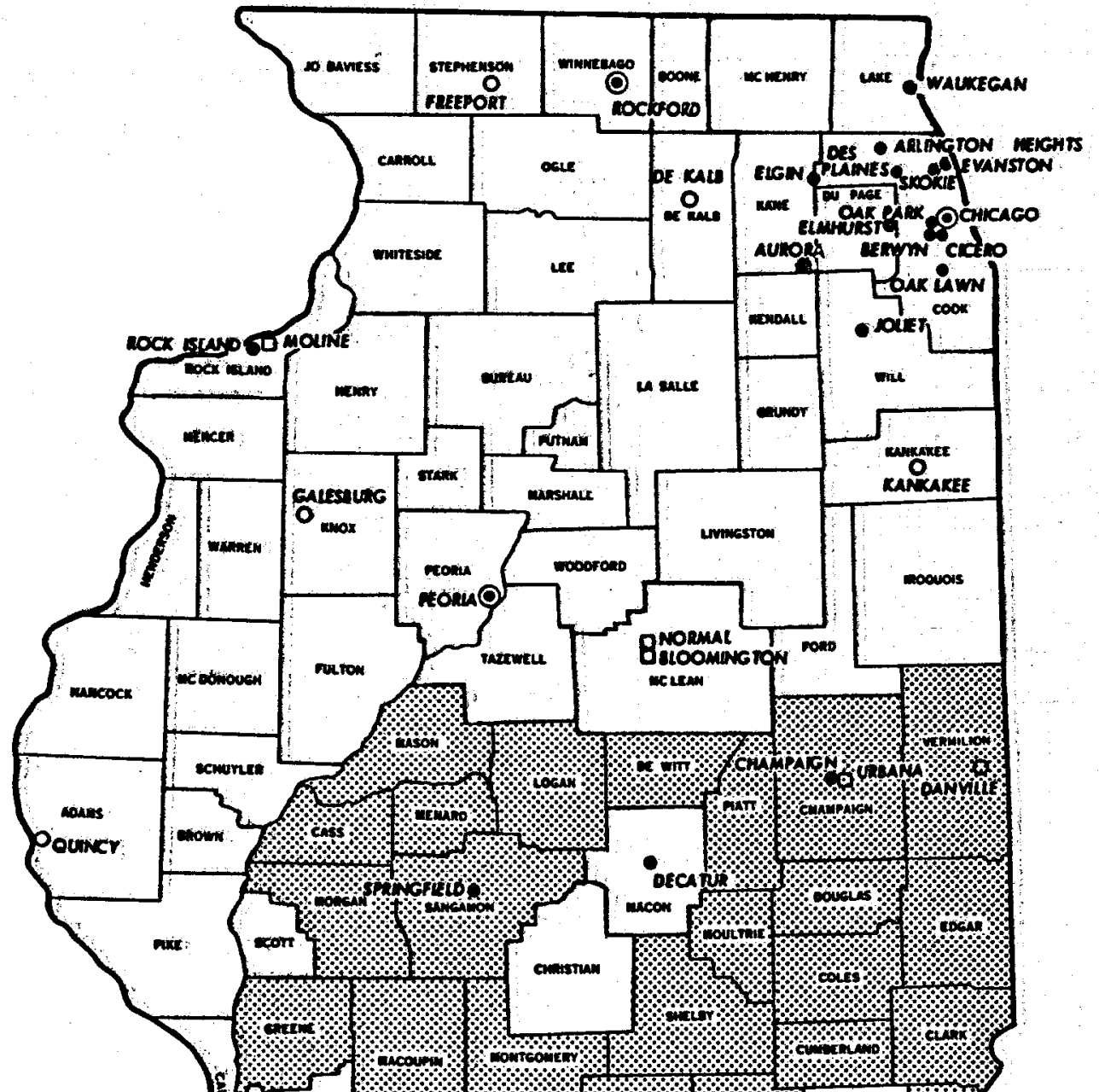

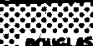
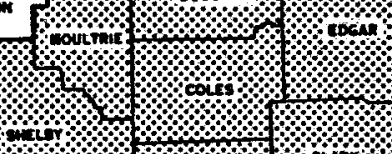

80 
THE JOHNS HOPKINS UNIVERSTTY APPLIED PHYSICS LABORATORY

LAUREL. MAAYLAND

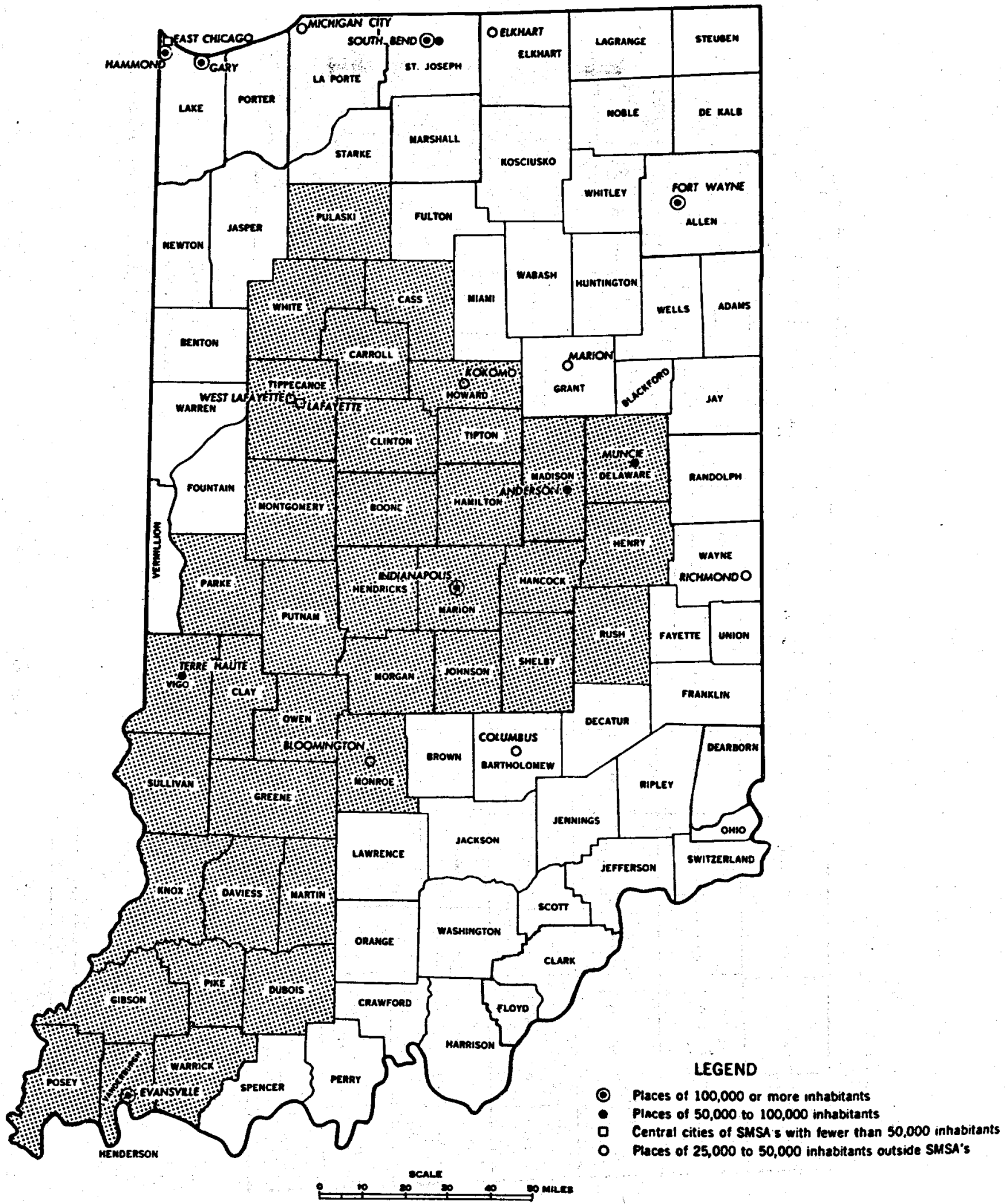

Fig. A-5 Indiana.

- 39 - 


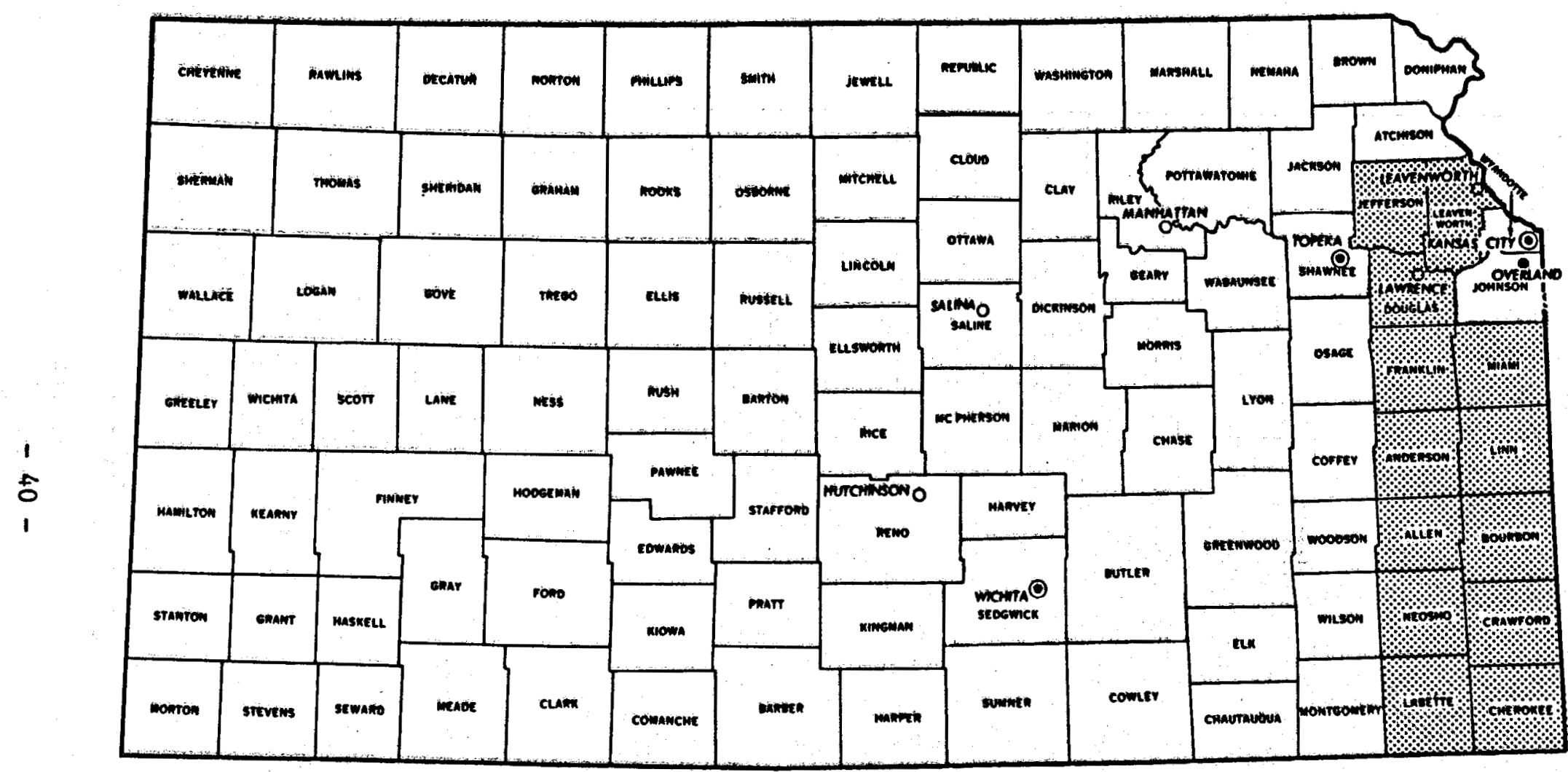

\section{LEGEND}

(1) Praces of 100,000 or more intiabitants

- Places of 50,000 to 100,000 inhabitants

- Places of 25,000 to \$0,000 inhabitants outside SMSA's

Fig. A-6 Kansas. 
THE JOHNS HOPKINS UNIVERSITY

APPLIED PHYSICS LABORATORY

laupel, marylano

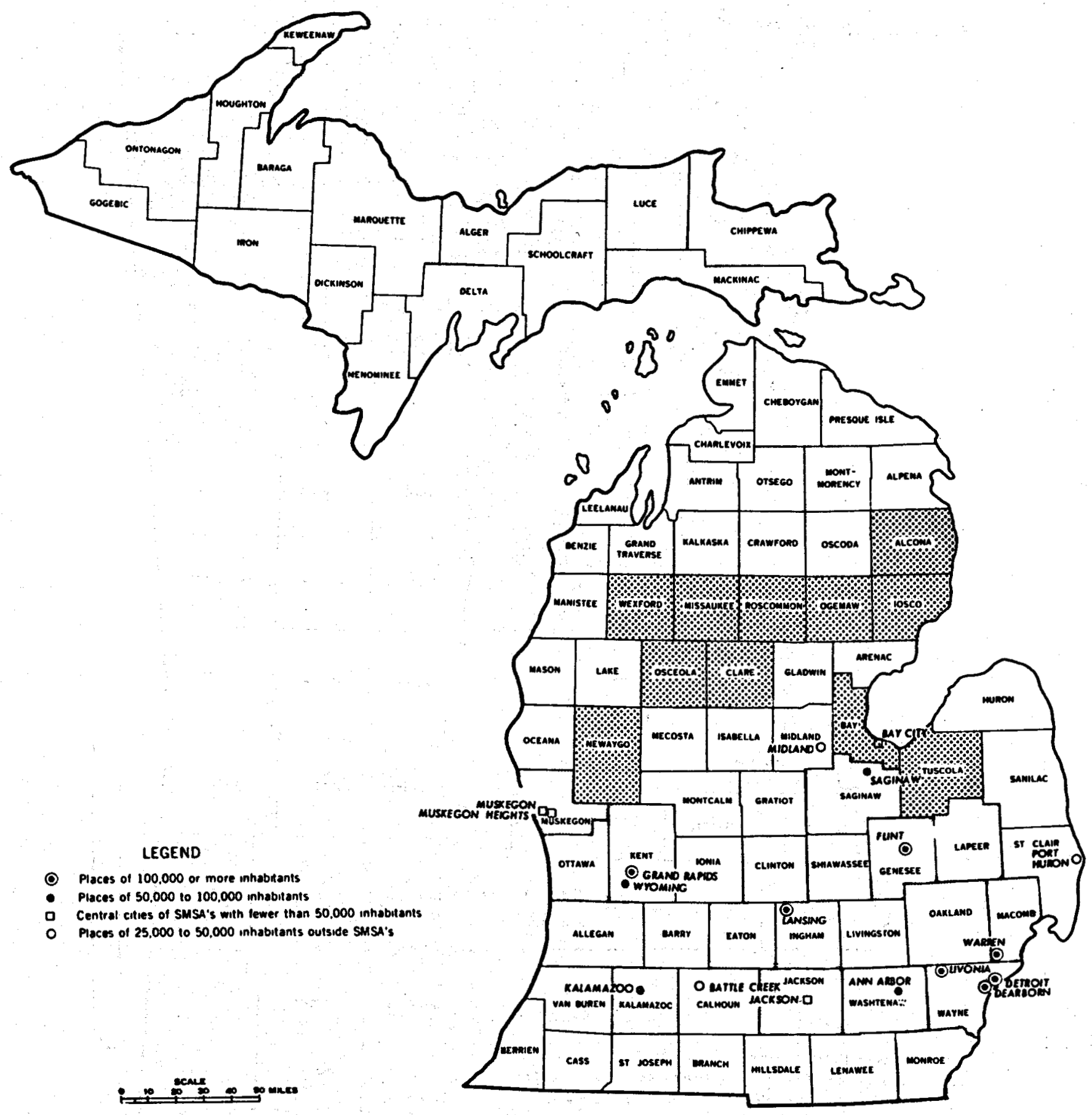

Fig. A-7 Michigan. 
THE JOHNS HOPKINS UNMERSTY APPLIED PHYSIGS LABORATORY

LAUREL, MaAYLAND

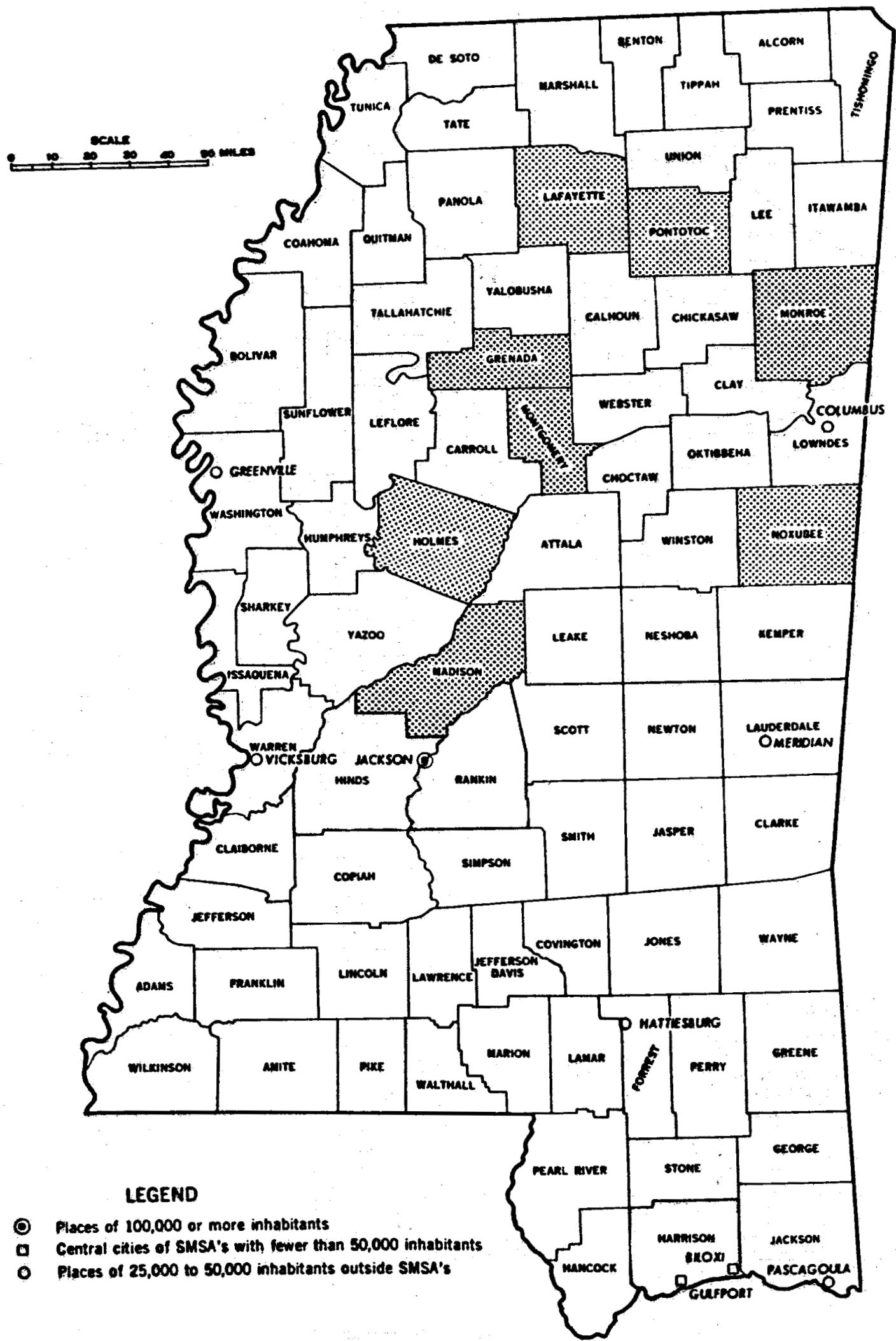

Fig. A-8 Mississippi.

$$
-42 \text { - }
$$


THE JOHNS HOPKINS UNIERSTY

APPLIED PHYSICS LABORATORY

LaUREL, MARYLAND

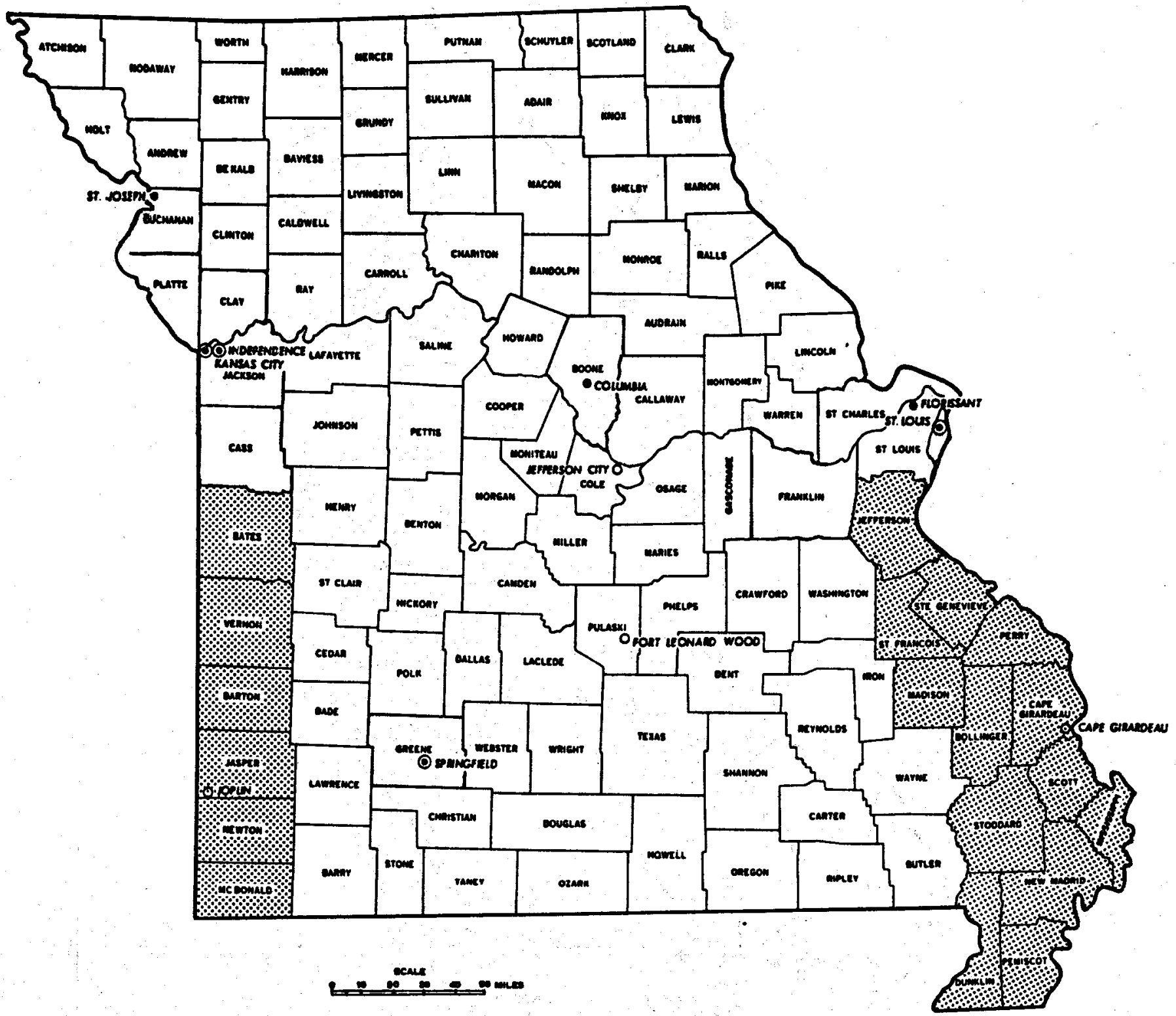

LEGEND

Maces of 100,000 or more mhobeents

Places of 50,000 to 100,000 mhabrents

Praces of 25,000 to 50,000 mhabrtents outside sugh's

Fig. A-9 Missouri. 


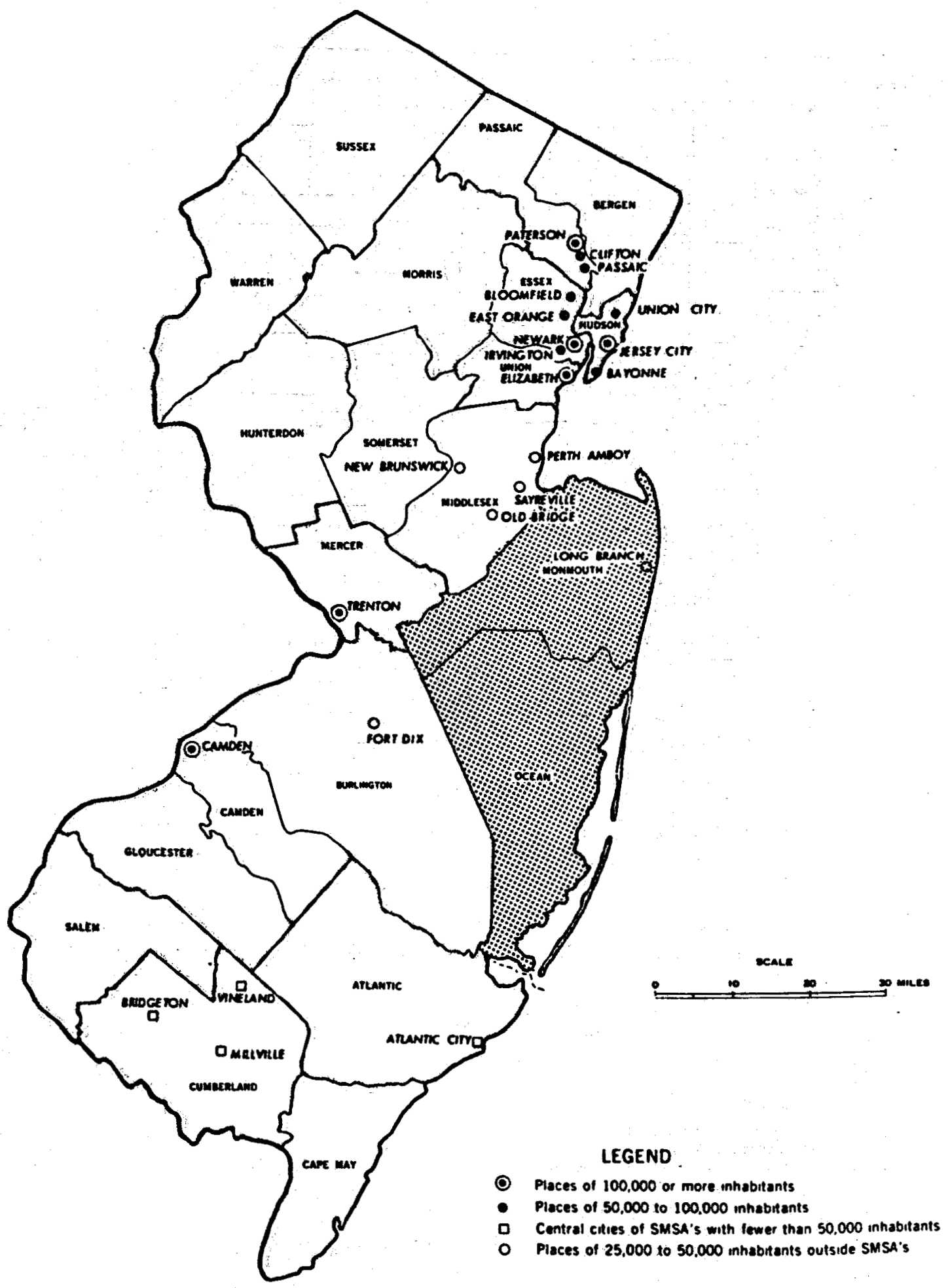

Fig. A-10 New Jersey. 



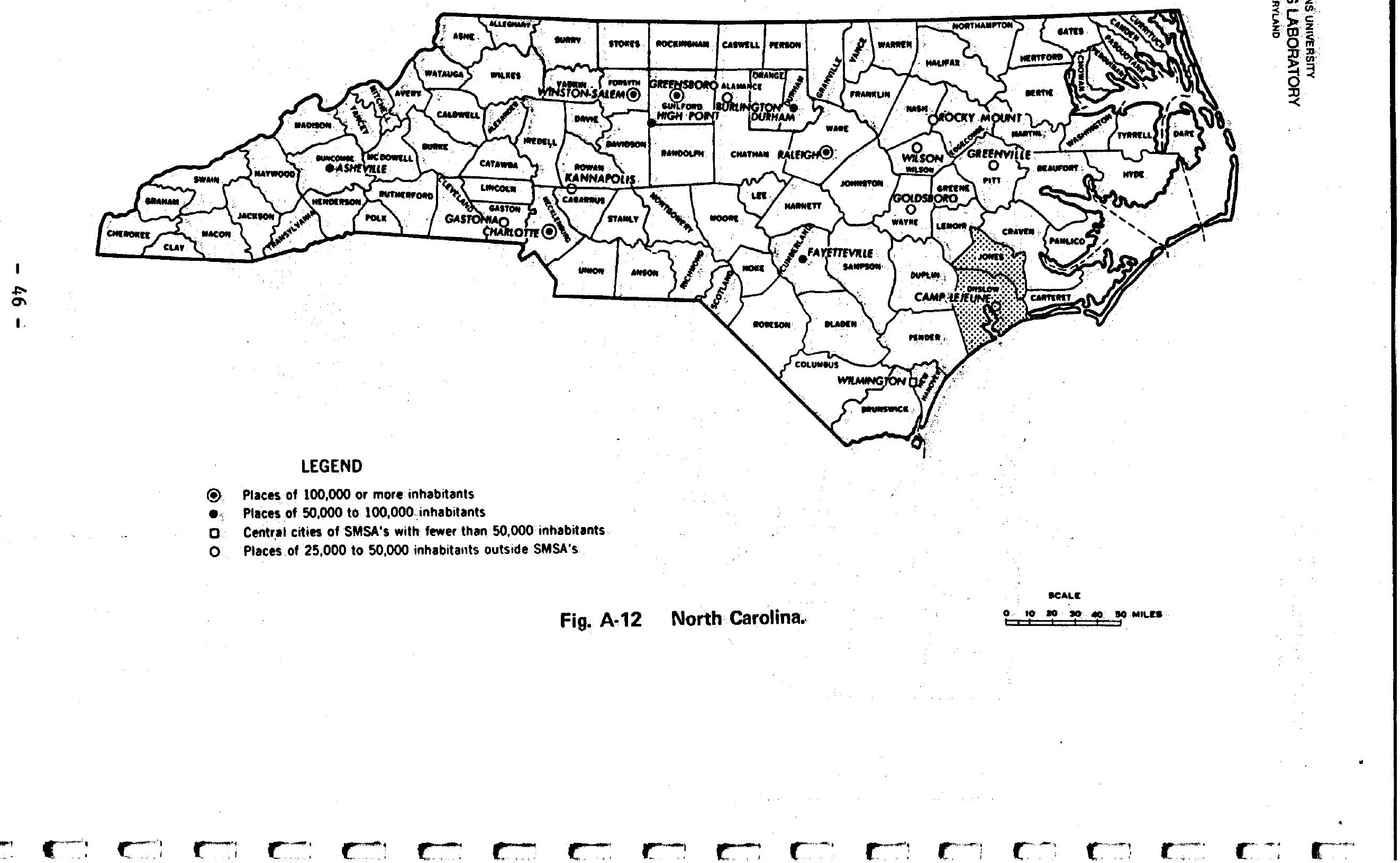


THE JOHNS HOPKINS UNIVEASITY APPLIED PHYSICS LABORATORY LAUREL, MARYLAND

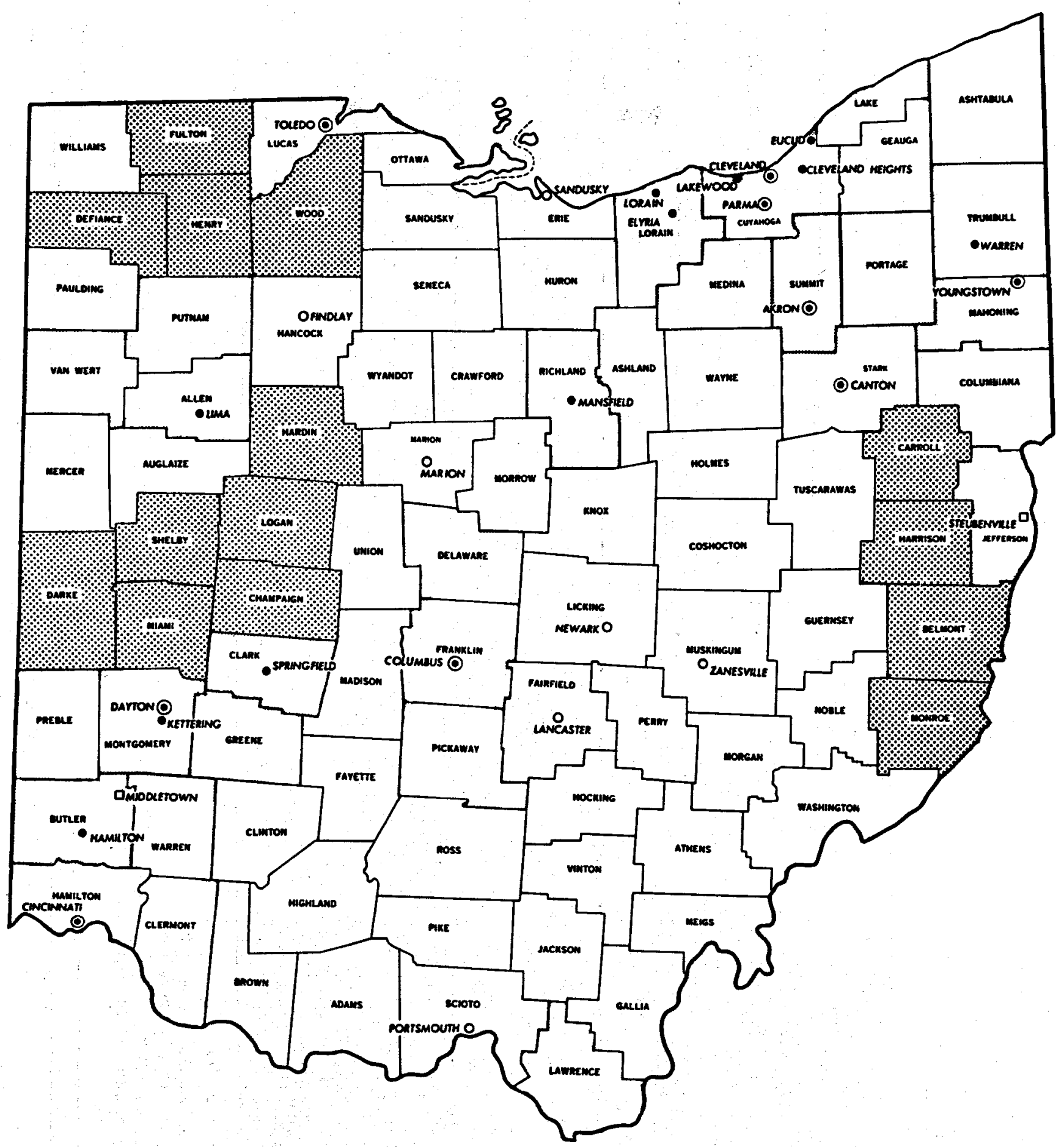

LEGEND

- Places of 100,000 or more inhabitants

- Places of 50,000 to 100,000 mhabitants

a Central citues of SMSA's with fewer than 50,000 inhabitants Places of 25,000 to 50,000 inhabitants outside SMSA's

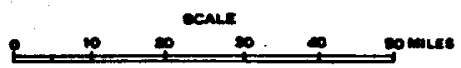

Fig. A-13 Ohio. 


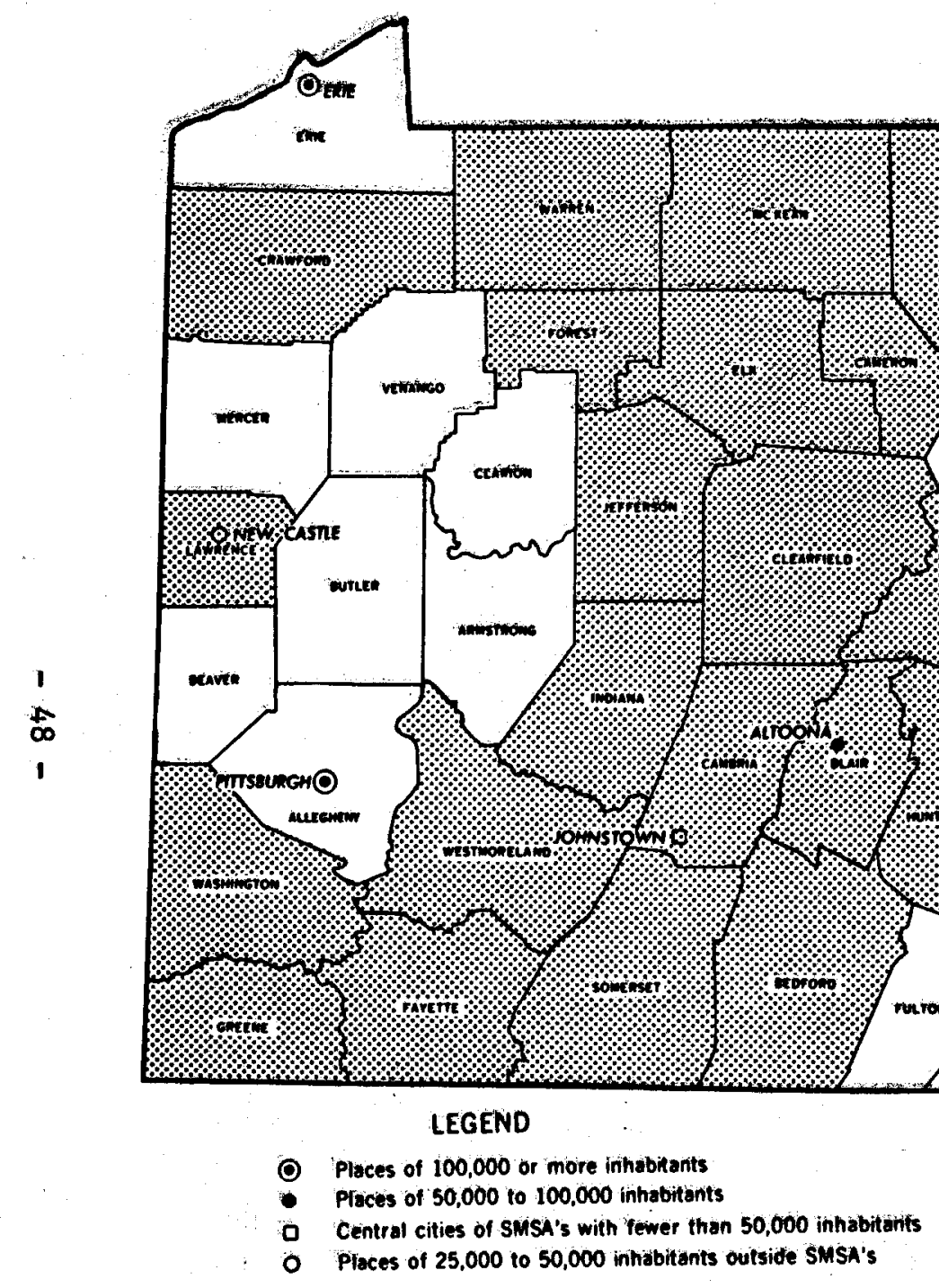

Fig. A-14 Pennsylvania.

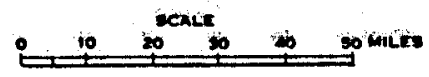




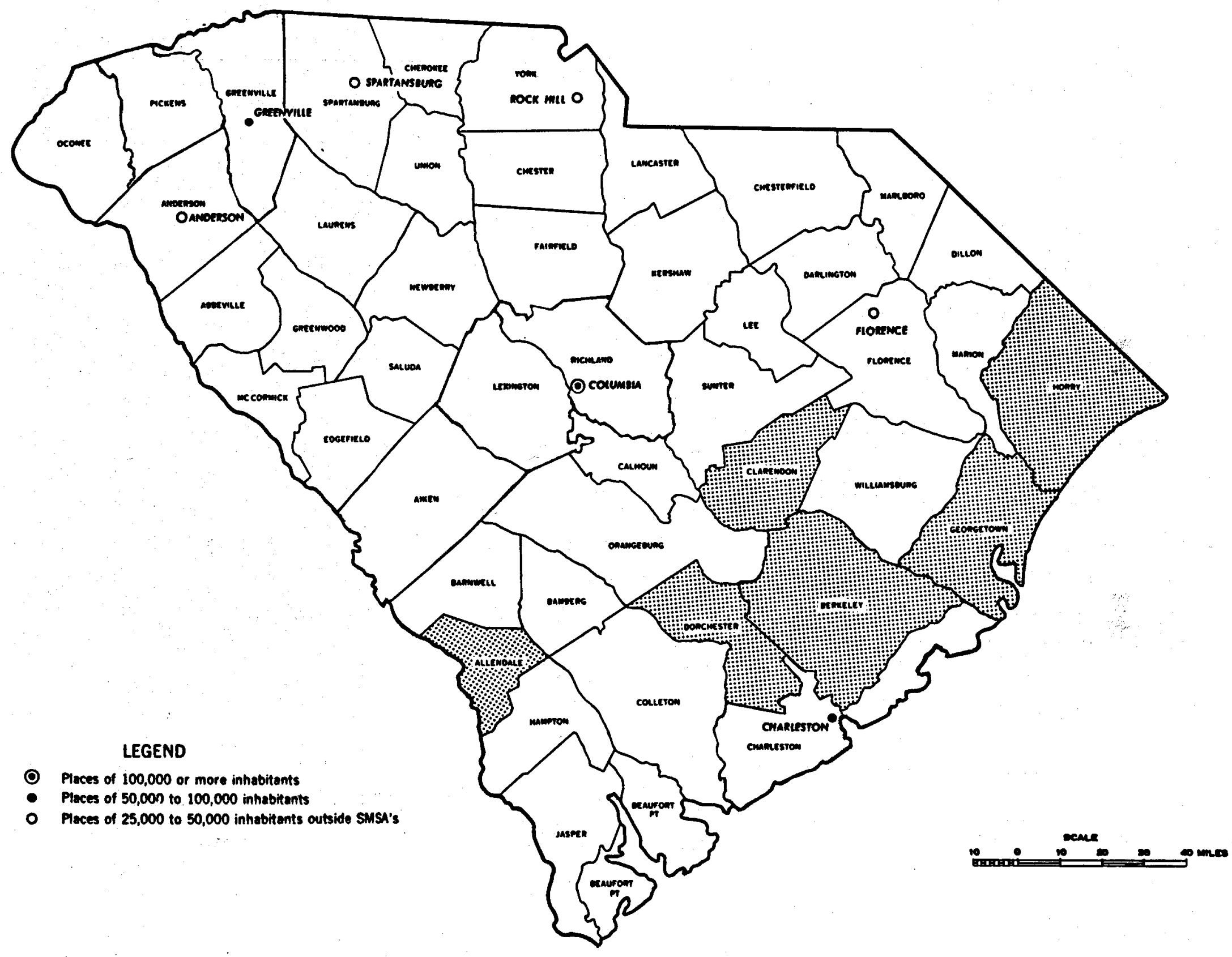

\section{Fig. A-15 South Carolina.}



THE JOHNS HOPKINS UNIVERSITY APPLIED PHYSICS LABORATORY LAUREL. MARYLANO

\author{
APPENDIX B \\ Ranked Prospects under Different Criteria
}





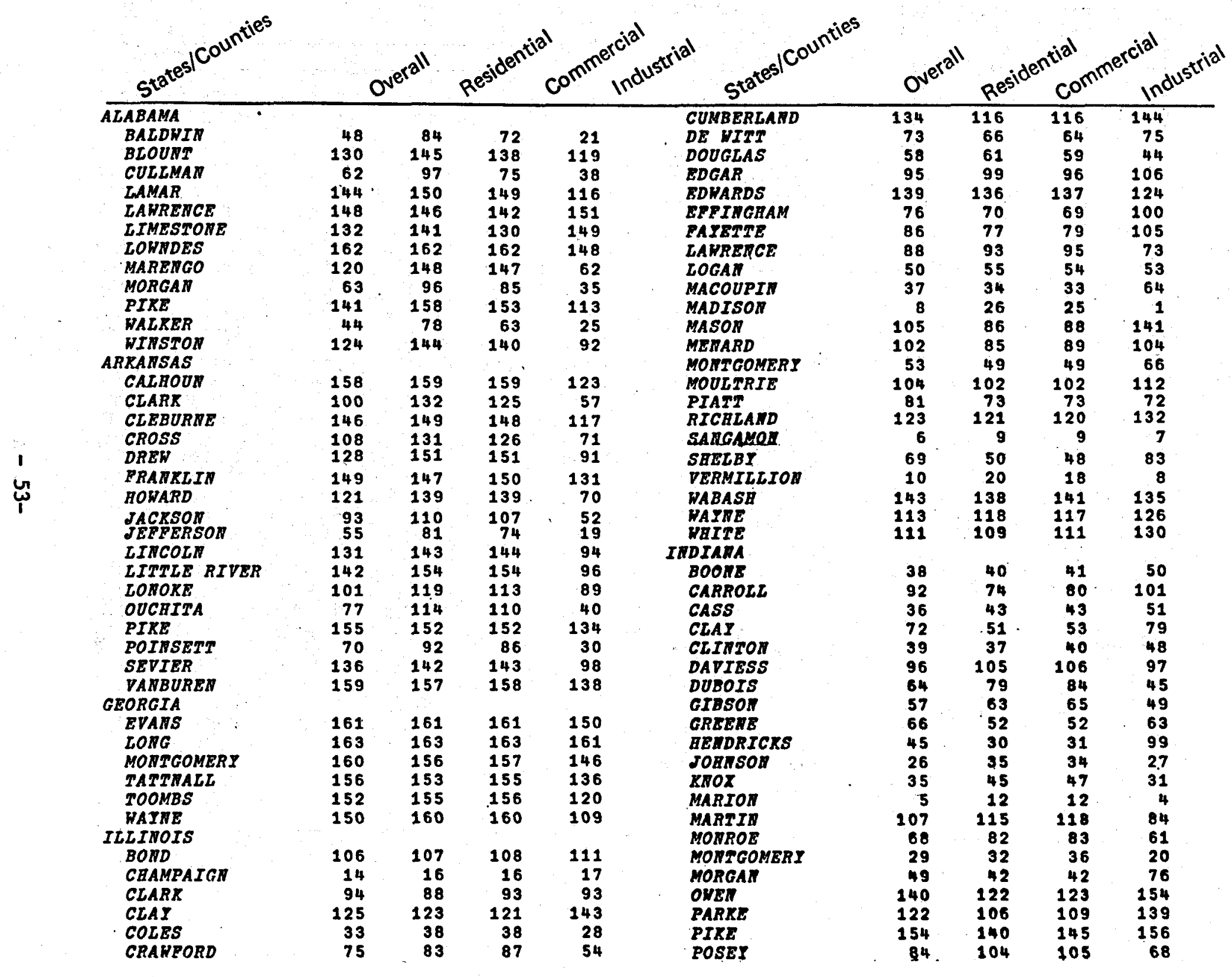




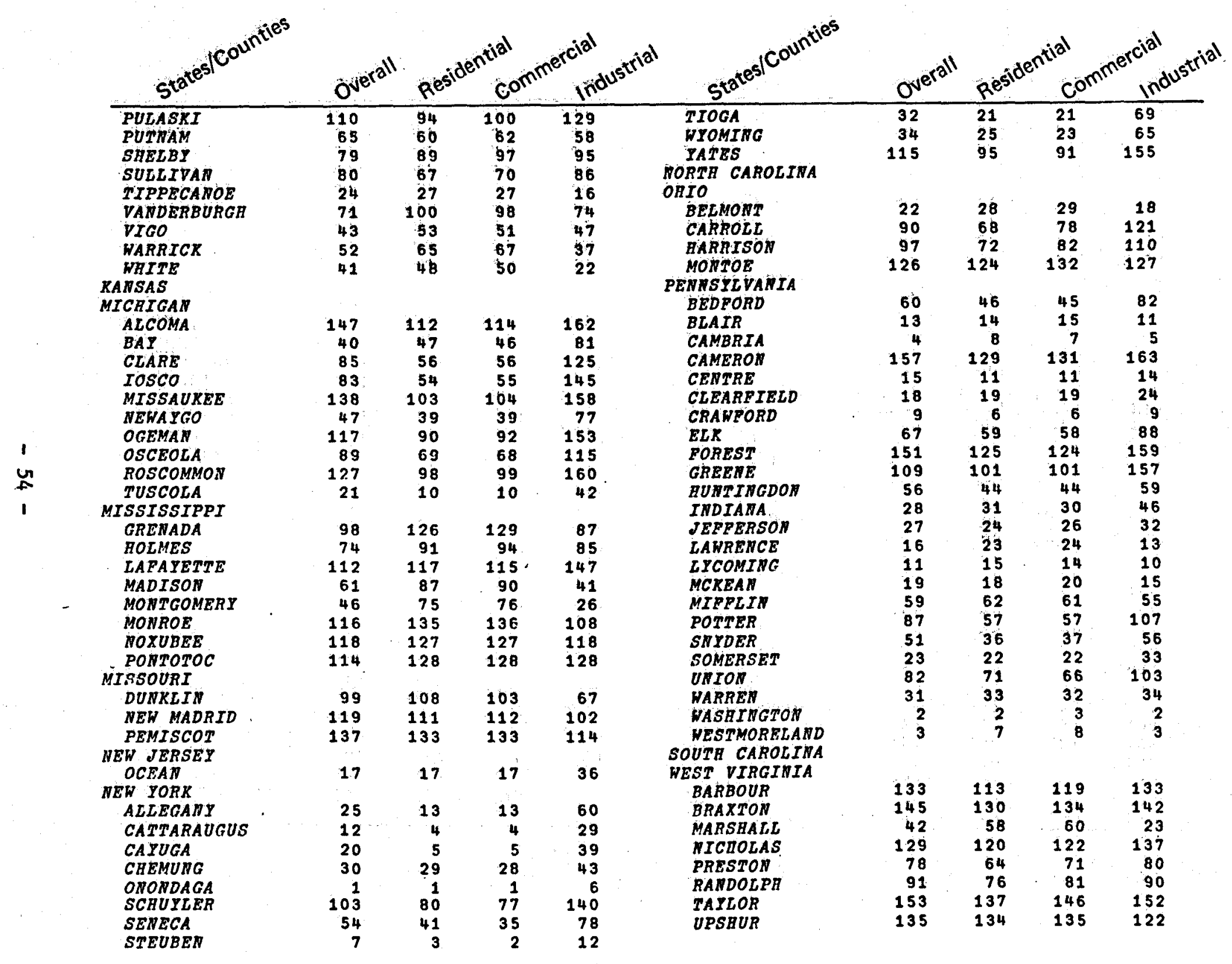




\section{INITIAL DISTRIBUTION EXTERNAL TO THE APPLIED PHYSICS LABORATORY*}

QM-79-163/GT

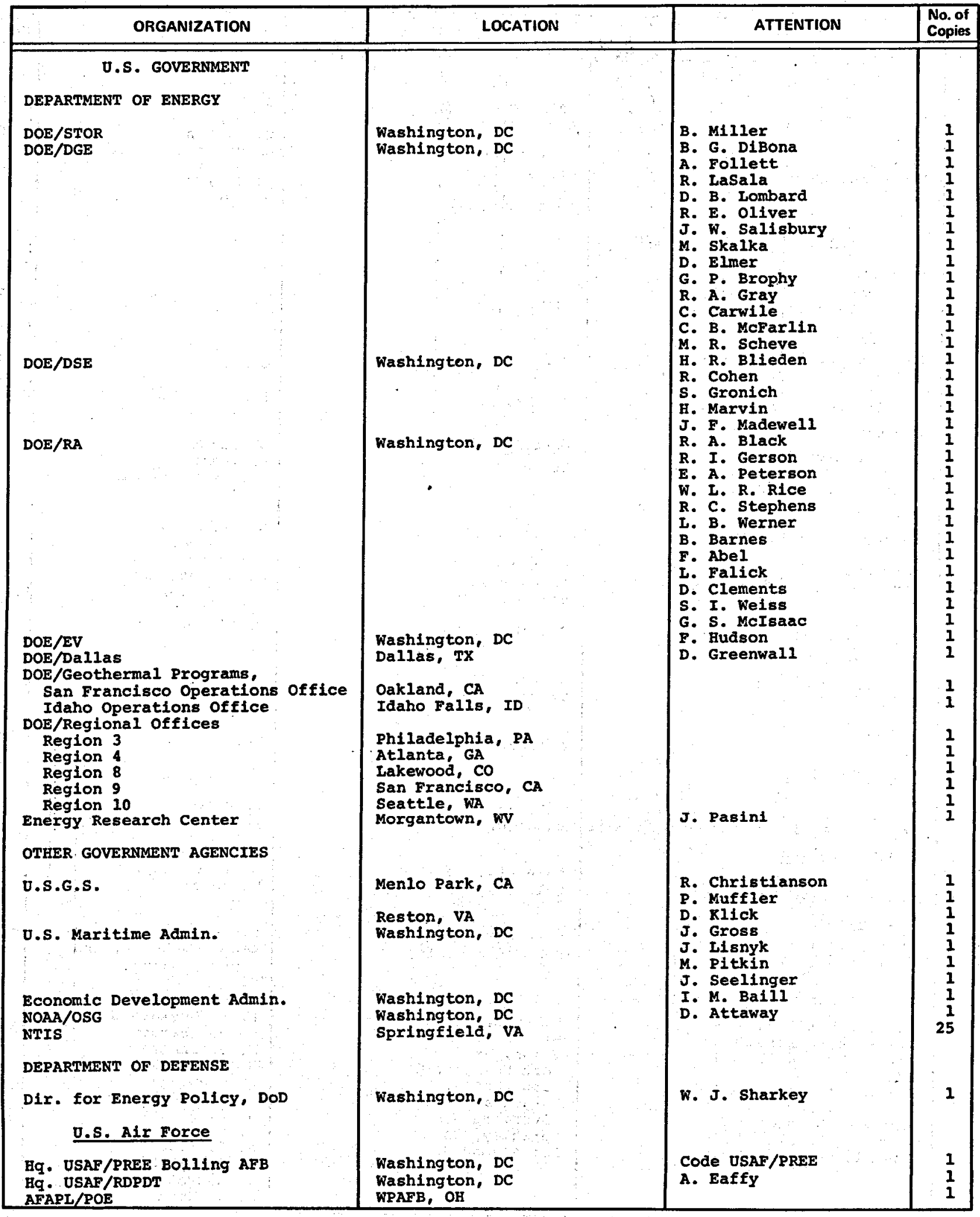

-Initial distribution of this document within the Applied Physics Laboratory has been made in accordance with a list on file in the APL Technical Publications Group. 
INITIAL DISTRIBUTION EXTERNAL TO THE APPLIED PHYSICS LABORATORY

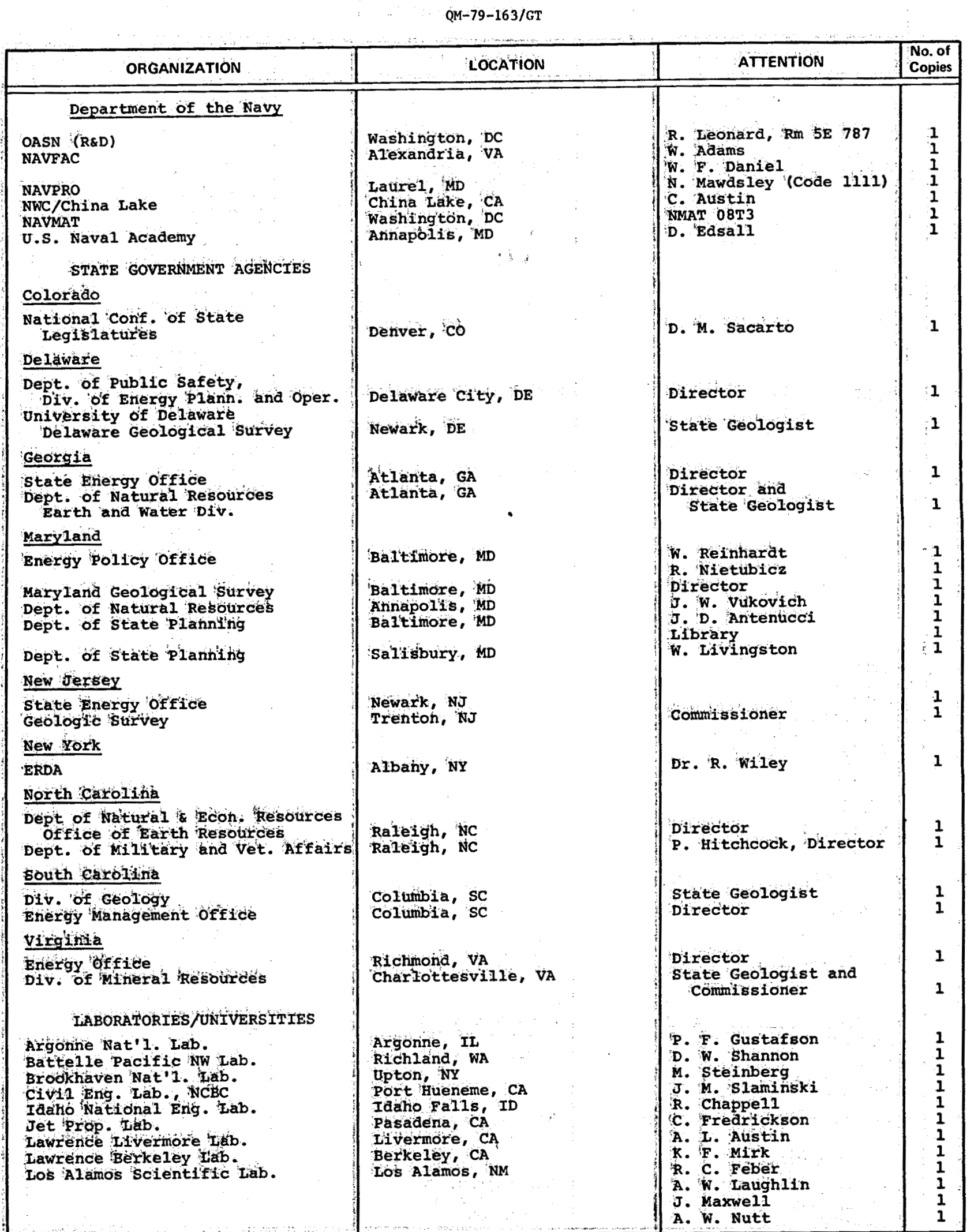


INITIAL DISTRIBUTION EXTERNAL TO THE APPLIED PHYSICS LABORATORY

QM-79-163/GT

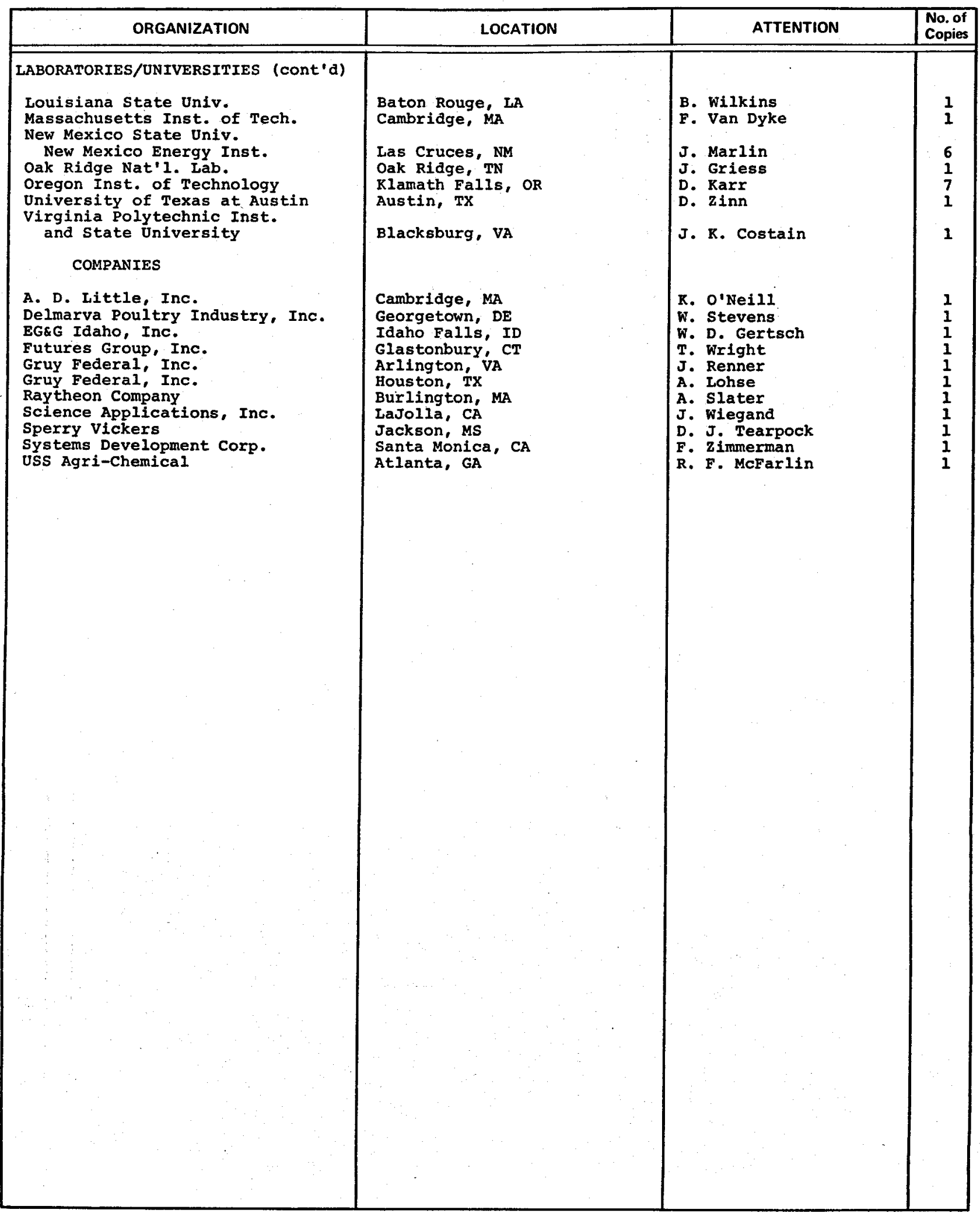

